PIOTR LASEK

Warszawa, Instytut Sztuki PAN

\title{
Kasper Sadłocha Niżeński herbu Korczak jako inwestor, dostawca budowlany i królewski praefectus fabricae
}

$\mathrm{P}$ ostać Kaspra Sadłochy Niżeńskiego pozostawała dotąd na marginesie zainteresowań badaczy architektury Warszawy XVI w. Doczekał się on wprawdzie obszernego hasła (autorstwa Henryka Rutkowskiego i Andrzeja Sołtana) w Polskim Stowniku Biograficznym, gdzie zebrano najważniejsze dane o życiu i działalności publicznej kanonika, jednakże charakter publikacji nie pozwolił autorom na dokładne prześledzenie poszczególnych wątków jego kariery ${ }^{1}$. W kontekście omawianej problematyki nie sposób pominąć artykułu Jadwigi Karwasińskiej, która jako pierwsza powiązała anonimowy wówczas Szafunek pieniędzy na budowanie dworu warszawskiego tak drzewem jako murem z nadzorcą budów królewskich, kanonikiem Sadłochą ${ }^{2}$. Ostatnio zainteresował się nim również Jacek Gajewski, który wszakże ujął w swych rozważaniach jedynie krótki epizod z długiej działalności Kaspra Niżeńskiego ${ }^{3}$. Tymczasem jego aktywność publiczna w dużej mierze związana była właśnie $\mathrm{z}$ architekturą, a skala i zakres powierzanych mu przedsięwzięć pozwalają sądzić, że był osobą doskonale zorientowaną w realiach ówczesnych inwestycji budowlanych. Co więcej, prócz nadzoru i realizacji królewskich przedsięwzięć Sadłocha konsekwentnie realizował także własne. Informacje o jego siedzibach dostarczają wiele wiadomości na temat horyzontów umysłowych Sadłochy oraz aspiracjach i aktywności inwestycyjnej ówczesnych przedstawicieli stanu szlacheckiego ${ }^{4}$. Ten

\footnotetext{
${ }^{1}$ Henryk RUTKOWSKI, Andrzej SOŁTAN, „Sadłocha (Sadłoch, Sadłochius) Niżeński Kasper h. Korczak (ok. 15161603)", [w:] Polski Stownik Biograficzny, t. XXXIV, red. Henryk MARKIEWICZ, Wrocław-Warszawa-Kraków 19921993, s. 280-282.

2 Jadwiga KARWASIŃSKA, „Materiały do dziejów budowy zamku warszawskiego w latach 1569-1572 zaczerpnięte z księgi rachunkowej Stanisława Fogelwedra i z odnoszących się do niej kwitów”, Rocznik Warszawski, 18:1985, s. $197-214$.

3 Jacek GAJEWSKI, „Od dworu-wieży mieszkalnej kanonika Sadłochy Niżeńskiego - do prywatnej własności Zygmunta III. Uwagi w sprawie przemian terenu i zabudowy późniejszego kompleksu architektonicznego Warszawskiego Towarzystwa Dobroczynności zw. Res Sacra Miser (i inne uwagi)", Arteria, 11:2013, s. 89-116. Praca ta została jednakże oparta jedynie na literaturze przedmiotu, bogaty zbiór archiwaliów, dotyczących Sadłochy, a przechowywany w zasobach Archiwum Głównego Akt Dawnych w Warszawie nie został przez Gajewskiego wykorzystany.

${ }^{4}$ Rozszerzenie tego typu badań słusznie postulował Leszek Kajzer; zob. Leszek KAJZER, „Od renesansowych dworów do pałaców «zimnego baroku». Rezydencje w Polsce Centralnej w XVI-XVIII wieku”, [w:] Residentiae tempore belli et pacis, red. Piotr LASEK, Piotr SYPCZUK, Warszawa 2019, s. 78 (Materiały do badań i ochrony założeń rezydencjonalnych i obronnych, 2).
} 
aspekt działalności Kaspra poruszyli Łukasz Traczyk oraz autor niniejszego tekstu, odnosząc się jednakże jedynie do zagadnień związanych z jego siedzibą przy Krakowskim Przedmieściu ${ }^{5}$. Warszawska działalność inwestycyjna kanonika wykracza daleko poza poruszane $\mathrm{w}$ wymienionym artykule zagadnienia i nie została jak dotąd dostatecznie naświetlona. Mam nadzieję, że przeprowadzona przeze mnie kwerenda źródłowa pozwoli zmienić ten stan rzeczy ${ }^{6}$.

Kasper Niżeński Sadłocha herbu Korczak, choć przez większą część życia zawodowego związany z Mazowszem i Warszawą, pochodził z Małopolski. Na świat przyszedł w królewskim mieście Osieku w ziemi sandomierskiej, gdzie jego ojciec Jan był rajcą ${ }^{7}$. Dwie siostry Kaspra - Katarzyna i Dorota, zostały wydane za sandomierskich aptekarzy: pierwsza za Bartłomieja Bergera, druga zaś za Stanisława z Piotrkowa ${ }^{8}$. Trzecia siostra, Anna, wyszła za mąż za Macieja Branwickiego, nadwornego krawca hetmana Jana Tarnowskiego ${ }^{9}$. Krag rodzinny Kaspra oddaje jego pozycję społeczną. Trudno tu mówić o (jak chce Jacek Gajewski) prestiżu, wynikającym z pochodzenia Sadłochy ${ }^{10}$. Feliks Kiryk zaliczył go w poczet patrycjatu miejskiego ${ }^{11}$. Kasper bowiem, choć pieczętował się herbem Korczak, jednocześnie pisał się z Osieka ${ }^{12}$, przez większość życia pozostając szlachcicem miejskim $^{13}$. Związki rodzinne i ekonomiczne z mieszczaństwem nie przeszkadzały mu jednak uważać się za pełnoprawnego przedstawiciela stanu szlacheckiego. Problem istnienia w miastach Korony szlachty miejskiej był długo marginalizowany w literaturze przedmiotu. Ostatnio zjawisku temu poświęcił swą pracę Leszek Belzyt.

\footnotetext{
5 Piotr LASEK, Łukasz TRACZYK, „Od wieży mieszkalnej Kaspra Sadłochy do zamku Adama Kazanowskiego. O aktualności średniowiecznego archetypu siedziby feudalnej po czasy «Potopu»”, Barok. Historia-Literatura-Sztuka, XXII:2015, nr 1, s. 129-149.

${ }^{6}$ Kwerenda objęła następujące zespoły, przechowywane w Archiwum Głównym Akt Dawnych w Warszawie (dalej: AGAD): Księgi grodzkie i ziemskie warszawskie, serie: Acta terrestria et castrensia Varsoviensia z lat 1421-1579 (dalej: GW) oraz Libri donationum et perpetuarum transactionum z lat 1579-1599 (dalej: GW, donationum); Księgi miejskie Starej Warszawy, (dalej: SW); Metryka Koronna Libri Inscriptionum (dalej: MK). W tym miejscu pragnąłbym złożyć serdeczne podziękowania Tomaszowi Płóciennikowi za trud włożony w tłumaczenie uzyskanych podczas kwerend materiałów.

${ }^{7}$ RUTKOWSKI, SOŁTAN, op. cit., s. 281. W 1524 r. w Metryce Koronnej wzmiankowany został Stanisław Sadłocha, wójt Osieka, zapewne także krewny Sadłochy; zob. AGAD, MK, 36, k. 503-504.

${ }^{8}$ Feliks KIRYK, Lekarze i aptekarze sandomierscy z przełomu XVI i XVII stulecia, Sandomierz 1987, s. 32. Sadłocha utrzymywał ze swoimi szwagrami bliskie kontakty rodzinne, skoro po śmierci siostry Doroty oraz Stanisława z Piotrkowa wziął pod opiekę ich małoletnie potomstwo - syna Szymona oraz córki Dorotę i Katarzynę; zob. AGAD, SW, 6, k. 130v.-131; 421-421v.

${ }^{9}$ RUTKOWSKI, SOŁTAN, op. cit., s. 281. W 1550 r. Jan Tarnowski wydzierżawił krawcowi Maciejowi Branwickiemu plac przy ulicy św. Marii Magdaleny. Dzierżawca miał na nim wybudować dom i prowadzić handel lub produkować różne rodzaje trunków; zob. Dominika BURDZY, „Szlachta w Sandomierzu w XVI i na początku XVII wieku”, Klio. Czasopismo poświęcone dziejom Polski i powszechnym, 42:2017, s. 37. Po zgonie Macieja i Anny Kasper Sadłocha występował jako pełnomocnik swego siostrzeńca, Adama Branwickiego, pomagając mu m.in. w zbyciu dóbr po matce, położonych w Osieku i Sandomierzu; zob. Księga wpisów podkanclerzego Wojciecha Baranowskiego z okresu marzec 1588-grudzień 1590 MK 135 z Archiwum Głównego Akt Dawnych w Warszawie, oprac. Wojciech KRAWCZUK, Michał KULECKI, Warszawa 2010, nr 59 i 60, s. 37 (Sumariusz Metryki Koronnej, Seria Nowa, IV, red. Wojciech KRAWCZUK).

${ }^{10}$ GAJEWSKI, op. cit., s. 92.

${ }^{11}$ KIRYK, op. cit., s. 28.

12 Edmund MAJKOWSKI, Aleksander BASTRZYKOWSKI, Nieznani prałaci i kanonicy kolegiaty Panny Marii w Sandomierzu od trzynastego do osiemnastego wieku, Kunów 1949, s. 8.

${ }^{13}$ Dopiero od 1594 r. dzierżył dożywotnio wieś Chrosna wraz z trzema sąsiednimi osadami; zob. Władysław PAŁUCKI, Drogi i bezdroża skarbowości polskiej XVI i pierwszej połowy XVIII wieku, Wrocław-Warszawa-Kraków-Gdańsk 1974, s. 194. W 1596 r. został przez Wojciecha Świnoleskiego wwiązany w wieś Drozdy.
} 
Badacz ten skonstatował, że już od schyłku XV stulecia, w związku z korzystnym rozwojem miast i mieszczaństwa trwał napływ do ośrodków miejskich biedniejszych przedstawicieli stanu szlacheckiego, szukających tam możliwości awansu finansowego ${ }^{14}$. Ludzie ci imali się przy tym typowo mieszczańskich zajęć, jak handel czy rzemiosło ${ }^{15}$. Część z nich, nie mogąc lub nie chcąc podejmować podobnych form zarobkowania, zajmowała różnego rodzaju posady w aparacie administracyjnym państwa oraz na dworach możnowładczych, a także służyła w wojskach zaciężnych ${ }^{16}$. Nota bene, przyjąwszy prawo miejskie osoby te często nadal formalnie pozostawały szlachcicami ${ }^{17}$. Proces separacji stanu szlacheckiego nie był, jak widać, w XVI stuleciu zakończony, trwało wzajemne przenikanie się szlachty i mieszczaństwa.

Kasper Sadłocha był więc szlachcicem miejskim i jednocześnie niewątpliwie przedstawicielem elit Osieka. W tamtejszej szkole parafialnej odebrał też zapewne pierwsze nauki, następnie zaś najpewniej uczęszczał do szkoły kolegiackiej w Sandomierzu ${ }^{18}$. Zdobyte wykształcenie pozwoliło Sadłosze na zrobienie kariery na dworze królewskim. W niewyjaśnionych bliżej okolicznościach znalazł się w otoczeniu Bony ${ }^{19}$, w której kancelarii pracował aż do śmierci królowej w 1557 r. Z dworem swej mocodawczyni trafił też zapewne do Warszawy. Za swe usługi pobierał pensję w wysokości 100 złotych polskich, zapisaną na dochodach monarchini z jej dóbr mazowieckich ${ }^{20}$. Maria Bogucka słusznie zauważyła, że królowa ,niezręczna w stosunkach z senatorami i tak przez licznych możnych nie lubiana, dogadywała się [...] doskonale z ludźmi prostymi, ale o otwartych głowach, chętnymi do pracy i pomysłowymi. Wykształciła też cały sztab energicznych urzędników i działaczy gospodarczych, rekrutujących się głównie ze średniej i drobnej szlachty [...]"21. Do tej ostatniej kategorii ludzi królowej należał niewątpliwie Kasper Sadłocha. Po zgonie swej dotychczasowej mocodawczyni przeszedł on do kancelarii Zygmunta Augusta, który w 1558 r. potwierdził pensję Sadłochy, wiążąc ją z dochodami niegrodowego starostwa Osieck koło Garwolina ${ }^{22}$. Kontakty Kaspra z „królem młodym” mogły rozpocząć się zresztą jeszcze za życia Bony. Maria Bogucka zauważyła, że od schyłku lat 40. i początku lat 50. XVI w. trwał proces przechodzenia części współpracowników królowej na stronę Zygmunta Augusta ${ }^{23}$. W przypadku Kaspra Sadłochy nie doszło

\footnotetext{
${ }^{14}$ Leszek BELZYT, Szlachta w mieście rezydencjalnym. Szlacheccy obywatele Krakowa i Warszawy około 1600 roku (analiza porównawcza struktury), Zielona Góra 2011, s. 132. Autor nie wspomina o Sadłosze, niemniej oparł on swe rozważania na analizie przyjęć do prawa miejskiego Warszawy. Tymczasem Sadłocha pozostawał najpewniej niemal do końca życia obywatelem Osieka. Ostatnio problematyka szlachty w ośrodkach miejskich I Rzeczypospolitej podejmowana była także przez innych badaczy; zob. Zdzisław NOGA, „Szlachta w miastach Królestwa Polskiego, Rzeczypospolitej, Pomorza i Śląska w XIII-XVIII w. Uwagi wstępne”, Klio. Czasopismo poświęcone dziejom Polski i powszechnym, 42:2017, s. 3-5 (oraz inne artykuły zawarte w tym tomie); Tomasz JUREK, „Szlachta w mieście i pod miastem w średniowieczu”, Kronika Miasta Poznania, 2018, nr 1, s. 11-32 (tom w całości poświęcony problematyce szlachty w ośrodkach miejskich).

${ }^{15}$ BELZYT, op. cit., s. 59-61.

${ }^{16}$ Zob. Andrzej ZAJĄCZKOWSKI, Szlachta polska. Kultura i struktura, Warszawa 1993, s. 33; Aleksander BOŁDYREW, Piechota zaciężna w Polsce w pierwszej połowie XVI wieku, Warszawa 2011, s. 142.

${ }^{17}$ BELZYT, op. cit., s. 56, 137.

${ }^{18}$ RUTKOWSKI, SOŁTAN, op. cit., s. 281.

${ }^{19}$ Julian BARTOSZEWICZ, Kościoły warszawskie rzymsko-katolickie opisane pod względem historycznym, Warszawa 1855, s. 26.

${ }^{20}$ AGAD, MK, 91, k. 109.

${ }^{21}$ Maria BOGUCKA, Bona Sforza, Wrocław 2009, s. 232.

${ }^{22}$ AGAD, MK, 91, k. 109-109v.

${ }^{23}$ BOGUCKA, op. cit., s. 127.
} 


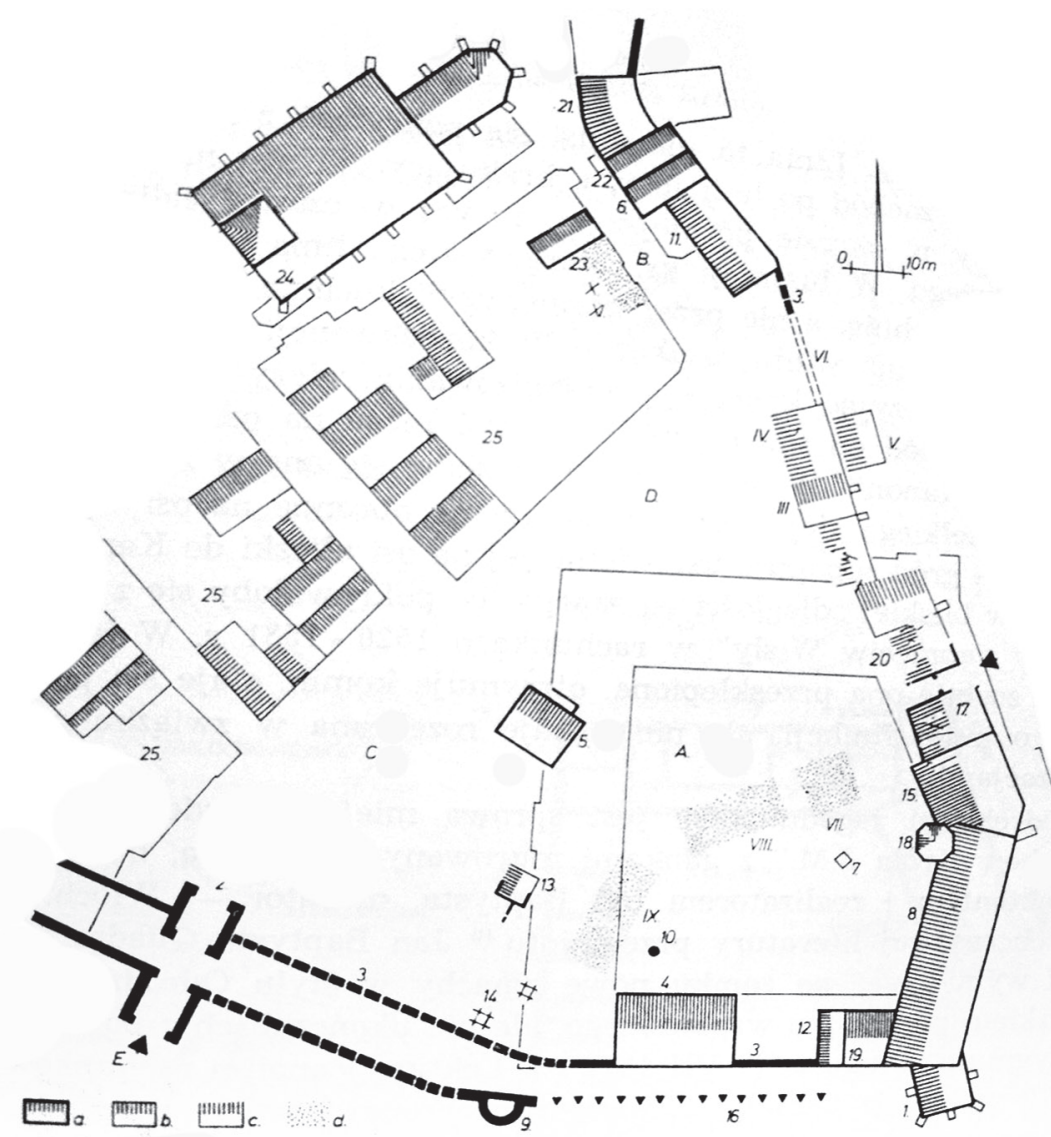

1. Zamek warszawski po przebudowie Zygmunta Augusta, próba rekonstrukcji rozplanowania, oprac. Antoni Kasinowski (1974)

zresztą nigdy do definitywnego zerwania więzi z królową Boną, skoro Zygmunt August w 1569 r. wzywał go w swym liście, aby zakomunikował wszystko, co wie o szkodach, poczynionych w spuściźnie po jego matce przez Pappacodę ${ }^{24}$.

Niewątpliwie związanie się z dworem Zygmunta Augusta otworzyło przed ambitnym Sadłochą nowe możliwości awansu. Na początku lat 60 . XVI w. dynamicznie rozwinęła się jego kariera kościelna. Przed 1560 r. był już kanonikiem warszawskim ${ }^{25}$. W 1562 r. wymieniono go jako plebana parafii osieckiejej ${ }^{26}$ zaś od roku 1567 występował również jako kanonik sandomierski (dzierżył ową godność do 1569) ${ }^{27}$. W 1566 r. w Osiecku staraniem Sadłochy zbudowano nowy, drewniany kościół w miejsce spalonego, zaś w 1568 wzmiankowano Kaspra już z tytułem podstarościego osieckiego ${ }^{28}$. Talenty organizacyjne kanonika musiały być wysoko cenione, Zygmunt August powierzył mu bowiem odpowiedzialne zadania nadzoru nad dwoma ważnymi inwestycjami warszawskimi. Od $1568 \mathrm{r}$.

\footnotetext{
${ }^{24}$ RUTKOWSKI, SOŁTAN, op. cit., s. 281.

${ }^{25}$ RUTKOWSKI, SOŁTAN, op. cit., s. 281. Ludwik Królik wymienia go z tą godnością już w 1548 r.; zob. Ludwik KRÓLIK, Kapituła kolegiacka w Warszawie do końca XVIII wieku, Warszawa 1990, s. 56.

${ }^{26}$ AGAD, MK, 93, k. 338v. Zob. też: Anna DUNIN-WĄSOWICZOWA, „Rejestr poboru od duchowieństwa archidiakonatu warszawskiego w 1561 r.", [w:] Warszawa XVI-XVII wieku, red. Alina WAWRZYŃCZYK, Andrzej SOŁTAN, Warszawa 1977, s. 123 (Studia Warszawskie, XXIV, 2).

${ }^{27}$ MAJKOWSKI, BASTRZYKOWSKI, op. cit., s. 8.

${ }^{28}$ RUTKOWSKI, SOŁTAN, op. cit., s. 281.
} 
2. Cieśla i strycharze przy pracy na placu budowy w XVI w., drzeworyt $z$ dzieła Piotra Crescentyna Kxięgi o gospodarstwie, y o opatrzeniu rozmnożenia rozlicznych pożytkow, każdemu stanowi potrzebne, Kraków 1549

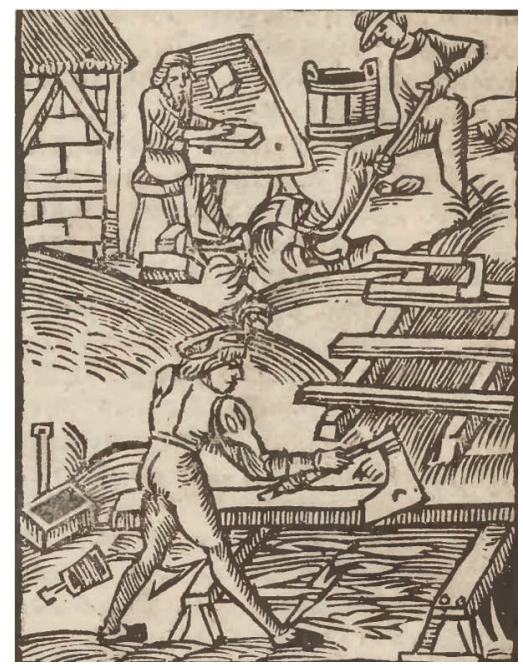

zarządzał budową pierwszego stałego mostu na Wiśle w Warszawie (we współpracy ze starostą warszawskim Zygmuntem Wolskim ${ }^{29}$ ), zaś od 1569 również rozbudową zamku warszawskiego $^{30}$ (il. 1). Jednocześnie nie ustawała jego działalność w Osiecku, najpewniej bowiem uczestniczył w lokacji miasta na gruntach tej miejscowości, zaś ok. 1570 r. założył w pobliżu wsie Regut i Gocław, których dochody oddał do skarbu królewskiego ${ }^{31}$. W latach 1570-1571 był wzmiankowany jako sekretarz Zygmunta Augusta ${ }^{32}$, zapewne pełnił tę funkcję do końca życia króla.

Szczęśliwie zachowany Szafunek pieniędzy na budowanie dworu warszawskiego tak drzewem jako murem $^{33}$ daje pojęcie o skali problemów, $\mathrm{z}$ jakimi musiał się w tym czasie borykać Sadłocha ${ }^{34}$. Jako królewski praefectus fabricae podejmował osobistą odpowiedzialność za różnorodne decyzje w procesie budowy, zarówno co do samych prac budowlanych, jak i zasadności wypłat, bezpieczeństwa oraz rozmaitych spraw administracyjnych (wyekwipowane posłańców, zorganizowanie transportu, zapewnienie prowiantu ludziom i zwierzętom zatrudnionym przy pracach). To właśnie on kierował wielonarodowym zespołem fachowców oraz robotników niewykwalifikowanych ${ }^{35}$. Wśród podległych mu ludzi zwłaszcza wśród cieśli (najliczniejszej, dodajmy, grupy rzemieślników na placu budowy) spotykamy największą różnorodność etniczną: Mazowszan (m.in. z Liwa, Sochaczewa)

\footnotetext{
29 „Warszawa w latach 1526-1795”, oprac. Maria BOGUCKA, Władysław TOMKIEWICZ, [w:] Dzieje Warszawy, t. II, red. Stefan KIENIEWICZ, Warszawa 1984, s. 28.

${ }^{30}$ KARWASIŃSKA, op. cit., s. 197-198.

${ }^{31}$ Janina LESKIEWICZOWA, Dobra osieckie w okresie gospodarki folwarczno-pańszczyźnianej XVI-XIX w., Wrocław 1957, s. 31.

${ }^{32}$ AGAD, SW, 6, k. 421-421v; AGAD, MK, 110, k. 123.

33 Obecnie jego fragmenty znajdują się w różnych zespołach AGAD: Archiwum Skarbu Koronnego (dalej: ASK), Dz. III, Rachunki nadworne, 1, k. 647-658 oraz 725-761; ASK, Dz. 1, Rachunki królewskie, 342, k. 82-97v; 348, k. 149-178 oraz 380/381/382, k. 252-282v. Całość publikowana w: Maria HAŁÓWNA, Jerzy SENKOWSKI, „,Materiały archiwalne do budowy zamku warszawskiego. Rachunki budowy z lat 1569-1572”, Teki Archiwalne, 2:1954, s. 192-400.

34 Trudno więc sądzić, iż, jak chce Jacek Gajewski, nadzorował jednocześnie budowę kilku innych realizacji królewskich, w tym dworu ujazdowskiego; zob. GAJEWSKI, op. cit., s. 91. Taki stan rzeczy nie znalazł, jak dotąd, potwierdzenia w źródłach pisanych.

${ }^{35} \mathrm{~W}$ literaturze przedmiotu można spotkać się z opiniami, że przebudową całości założenia królewskiego kierował Jan Baptysta Quadro, co jednak nie znajduje potwierdzenia w materiałach archiwalnych; zob. Jerzy LILEYKO, „Conclave Consiliorum et Officina Regum. Funkcje i ukształtowanie sal sejmowych na zamku w Warszawie w XVI i XVII w.”, [w:] Warszawa XVI-XVII wieku, s. 269; Michał WARDZYŃSKI, „Sztuka nowożytna na Mazowszu. Zarys problematyki”, [w:] Dzieje Mazowsza, t. II: Lata 1527-1794, red. Jan TYSZKIEWICZ, Pułtusk 2015, s. 644.
} 
oraz przybyszów z innych części Korony (głównie z Krakowa), Rusinów i Litwinów, a także Niemców z Prus, Gdańska oraz z ziem północnoniemieckich ${ }^{36}$, wreszcie zaś „Olendrów”, wykonujących ramy okienne i prace szklarskie ${ }^{37}$. Ekipa muratorów była natomiast złożona z „Włochów” (w rzeczywistości najczęściej mieszkańców rejonu Lugano, jak Jan Baptysta Quadro, Jakub Parr, Sylwester) oraz mniej licznych murarzy polskich $^{38}$ (il. 2). Ta grupa pracowników była związana kontraktami budowlanymi, które Sadłosze, skwapliwie notującemu wszelkie odstępstwa od zawartych postanowień, częściowo ułatwiały nadzór nad nimi ${ }^{39}$. Pozostawała jeszcze kwestia zatrudnienia innych specjalistów (kowali, ślusarzy, lepiarzy, traczy itp.), płatnych od dzieła, oraz zapewnienie odpowiedniej koordynacji prac. Sadłocha wykazywał się tu dużymi zdolnościami, w razie konieczności wzmożenia tempa prac na danym odcinku robót przerzucając pracowników lub całe ich zespoły z budowy mostu na Wiśle do budowy zamku i na odwrót ${ }^{40}$. Stosunkowo najwięcej miejsca zajmują w Szafunku... kwestie zapewnienia pomocy niewykwalifikowanej oraz transportu, przy czym należy zauważyć, że Sadłocha często zatrudniał do różnych zadań, wymagających niskich lub żadnych kwalifikacji, poddanych starostwa osieckiego ${ }^{41}$. Płacił im jednak takie same stawki jak innym pracownikom. Sprawy regulowania zobowiązań wobec rzemieślników, niewykwalifikowanej siły roboczej i dostawców zajmowały poczesne miejsce w codziennym harmonogramie zadań Kaspra, który starannie i skrupulatnie rejestrował każdy wydatek królewskich pieniędzy. Niekiedy zmuszony był moderować wystawione rachunki, notując wówczas fakt obcięcia części należności (,kowalowi Samsonowi podług jego regestu, ujmując jedno u niektórych rzeczy, gdzie drogo kładł" 42 , podobnie było też m.in. w przypadku malarza Mateusza ${ }^{43}$ ). Na Sadłosze spoczywała również odpowiedzialność za bezpieczeństwo placu budowy, stąd wśród wypłat regularnie powtarzają się pobory stróżów. Przeważnie pilnowali oni nad Wisłą wyładowanego z tratw i szkut materiału budowlanego ${ }^{44}$, choć znaleźć można także informację o zapłacie ,chłopu, co strzegł wina przez noc, gdy w zamku nie wstawione do piwnic stało" 45 .

Uderza dbałość Sadłochy o zdrowie i samopoczucie powierzonego mu zespołu ludzi. Kanonik skrupulatnie notował wszelkie poważniejsze wypadki na budowie, przy czym poszkodowanym wypłacał zapomogę (jak np. Janowi Mastin z Nadarzyna, któremu ,wóz ciężki zaszkodny nogi przejechał i zepsował, dałem mu na barwierza"46). Co więcej, wypłacał także zapomogi chorym bądź słabującym pracownikom, nawet jeśli choroba nie wynikała z wypadku przy pracy (np. choremu Niemcowi, towarzyszowi cieśli Izaaka ${ }^{47}$ ). Kasper przestrzegał skrupulatnie, aby w święta nie pracowano, zaś „cieślom polskim, iż

\footnotetext{
${ }^{36}$ HAŁÓWNA, SENKOWSKI, op. cit., s. 210-211, 234.

${ }^{37}$ Ibid., s. 269.

${ }^{38}$ Antoni KAূSINOWSKI, „Prace budowlane na zamku królewskim w Warszawie w świetle rachunków z lat 15691572", [w:], Warszawa XVI-XVII wieku, red. Alina WAWRZYŃCZYK, Andrzej SOŁTAN, Warszawa 1974, s. 87-88 (Studia Warszawskie, XX, 1).

${ }^{39}$ HAŁÓWNA, SENKOWSKI, op. cit., s. 270.

${ }^{40}$ HAŁÓWNA, SENKOWSKI, op. cit., s. 244; KASINOWSKI, op. cit., s. 88.

${ }^{41}$ HAŁÓWNA, SENKOWSKI, op. cit., s. 231, 232, 264, 274, 343, 345.

${ }^{42}$ Ibid., s. 228

${ }^{43}$ Ibid., s. 372.

${ }^{44}$ Np. ibid., s. 355

${ }^{45}$ Ibid., s. 233.

${ }^{46}$ Ibid., s. $275,300$.

${ }^{47}$ Ibid., s. 239-240.
} 
im święto wytracono, tedy jem na piwo dano"48. Piwem właśnie wynagradzał Sadłocha różnorodne prace, które wynikały z konieczności naprawiania błędów innych robotników (,stolarczykom od heblowania posadzki, od murarza nierówno położonej”49) lub też były szczególnie męczące („murarzom gdy dołamali muru do spuszczania dachu [...] bo się bardzo ukurzyli" ${ }^{50}$ ). Wydawał piwo również jako nagrodę po zakończeniu danego etapu robót $^{51}$ oraz za szczególnie trudne i niebezpieczne akcje (np. takie wynagrodzenie otrzymali chłopi, pomagający ratować ładunek jednej ze szkut, która uległa wywróceniu ${ }^{52}$ ).

Prócz konieczności panowania nad pracą i bezpieczeństwem pracowników „fabryki” zamkowej największą bolączką Kaspra Sadłochy było zgromadzenie odpowiedniej ilości i jakości materiałów budowlanych. Mimo ożywienia ruchu budowlanego w Warszawie od momentu inkorporacji miasta do Korony ${ }^{53}$, duża i prestiżowa realizacja, jaką była rozbudowa zamku warszawskiego, natrafiała na znaczne problemy materiałowe. Sadłocha dla ich pozyskania często wysyłał posłańców do różnych miejscowości na obszarze zarówno samego Mazowsza, jak i innych ziem Królestwa. Na przykład wapno sprowadzano z Zakroczymia ${ }^{54}$, Czerwińska i Radomia ${ }^{55}$, ale też z bardziej odległych lokalizacji: Nowego Miasta Korczyna ${ }^{56}$, Sandomierza, Krakowa, Miechowa ${ }^{57}$. Nie mniejszy problem był z dostarczeniem drewna: tarcice jodłowe spławiano znad Sanu, z Nowego Sącza oraz Krakowa $^{58}$, dębinę z Nowego Miasta Korczyna ${ }^{59}$, inne drewno (bez określenia gatunku) sprowadzano też z Bolimowa, Sochaczewa, Sokołowa, gonty zaś również z Sokołowa oraz z Kozienic i Radomia. Tak dalekie podróże po materiał można wytłumaczyć nie tylko naturalnym zasięgiem występowania niektórych gatunków czy też troską o odpowiednią jakość drewna, ale też możliwością darmowego uzyskania budulca z puszcz królewskich. Dwa kosze szkła okiennego (francuskiego), potrzebne do pracy wzmiankowanym „Olendrom" oraz szklarzowi z podwarszawskiego Piaseczna, sprowadzono z Gdańska ${ }^{60}$. Kafle piecowe do komnat zamkowych zakupiono w Siennie ${ }^{61}$. Kamień budowlany pozyskiwano ,ze starego muru"62, czyli z rozbiórki, a piasek z kopanych fundamentów, ale już kamień niezbędny do wykonania obramień okiennych i drzwiowych sprowadzano

\footnotetext{
48 Ibid., 241.

${ }^{49}$ Ibid. s. 269.

${ }^{50}$ Ibid., s. 315.

${ }^{51}$ Ibid., s. 209

52 HAŁÓWNA, SENKOWSKI, op. cit., s. 352.

${ }^{53}$ Problematyka rozwoju Warszawy w 2.-3. ćwierci XVI w. była wielokroć poruszana w literaturze przedmiotu. Historycy podkreślają w tym kontekście zwłaszcza napływ do miasta muratorów zarówno pochodzenia obcego (w latach 1540-1580 m.in. przyjęto do prawa miasta Warszawy kilkunastu muratorów z Italii), jak i rodzimych; zob. HAŁÓWNA, SENKOWSKI, op. cit., s. 193; Wanda SZANIAWSKA, „Zmiany w rozplanowaniu i zabudowie Krakowskiego Przedmieścia do 1733 r.”, Biuletyn Historii Sztuki, XXIX:1967, nr 3, s. 291; „Warszawa w latach 1526-1795...”, s. 19-20; Jarosław ZIELIŃSKI, Atlas dawnej architektury ulic i placów Warszawy, t. 7, Krakowskie Przedmieście, Warszawa 2001, s. 11; Benon DYMEK, Mazowsze. Historia i kultura 1526-1795, Pułtusk-Warszawa 2015, s. 79; Zbigniew MORAWSKI, „Miasta mazowieckie w XVI-XVIII wieku”, [w:] Dzieje Mazowsza..., s. 201-202.

${ }^{54}$ HAŁÓWNA, SENKOWSKI, op. cit., s. 194.

55 Ibid., s. 260.

56 Ibid., s. 305.

${ }^{57}$ Ibid., s. 320, 326.

${ }^{58}$ Ibid., s. 194, 309, 311.

${ }^{59}$ Ibid., s. 305.

${ }^{60}$ Ibid., s. 273.

${ }^{61}$ Ibid., s. 373.

62 Ibid., s. 272.
} 
z Krakowa ${ }^{63}$, Czerska ${ }^{64}$ i Kazimierza nad Wisłą (zapewne był tylko tam składowany) ${ }^{65}$ oraz z Melsztyna ${ }^{66}$. Ołów i blacha miedziana pochodziły z Krakowa ${ }^{67}$, a nawet gwoździe gontowe sprowadzono z Kozienic ${ }^{68}$. Najtrudniejsze jednak, jak się okazuje, było zaopatrzenie budowy w cegłę. Pochodziła ona z różnych źródeł, częściowo z cegielni miejskich ${ }^{69}$, ale również spławiano ją z Radomia oraz sprowadzano podwodami z Osiecka od tamtejszego wójta, Filipa Szlichtinga (podwody te byli obowiązani poddani osieccy dawać darmo ${ }^{70}$ ). Sam Sadłocha dostarczał dwukrotnie materiał budowlany, który, nota bene, miał przygotowany już od dawna w okolicach Kanonii na cmentarzu oraz w nieokreślonym bliżej spichlerzu $^{71}$. Kanonik dostarczył ponad 5000 cegieł, co jednak było kroplą w morzu potrzeb. Dochodziło do tego, że Sadłocha musiał uciekać się do pomocy darczyńców oraz pożyczek. I tak, w 1569 r. 10000 sztuk cegły darowali Radziejowscy, Oborscy zaś przysłali 2000 oraz poddanych celem dostarczenia i rozładunku materiałów. W 1571 r. pożyczył Sadłocha ,in deffectu cegły u mieszczan na różnych miejscach 6000 , którąśmy potem oddali [...]"72. Nie miał takiego szczęścia doktor Tomasz, który nie otrzymał zwrotu swych 4000 sztuk cegły, gdyż ta „się pożyczyła"73. W trudnym roku 1571 Sadłocha musiał uciekać się także do pożyczania wapna u niejakiej pani Sawłowskiej ${ }^{74}$ oraz dachówki u pobliskich Bernardynów ${ }^{75}$. Pożyczka ta była niezbędna z uwagi na fakt, że strycharze przysłani specjalnie z Krakowa dla wyrobu dachówki na miejscu, musieli zrezygnować z wykonania zadania z powodu złej jakości gliny ${ }^{76}$.

Schyłek lat 60. i początek lat 70. XVI w. były dla Kaspra Sadłochy czasem wytężonej pracy i wielu kłopotów organizacyjnych. Nie tylko bowiem nadzorował prestiżową monarszą inwestycję, ale sam występował w roli inwestora. Terminus post quem realizacji jego siedziby stanowić może wzmianka, odnaleziona przeze mnie w księgach miejskich Starej Warszawy. Otóż w 1570 r. „sławetny Walenty Kędziora, mieszczanin z Lubowli, [...] zeznał, że za pośrednictwem pewnych arbitrów [...] na mocy swego prawa do przelania i zrzeczenia się, udzielonego mu przez szlachetną Annę, rodzoną siostrę śp. wielebnego pana Andrzeja Świeborowskiego, kanonika warszawskiego, swoją zaś matkę, [...] ze względu na pewien dług zapisany na ogrodzie bez budynków przez sławetnego Marcina Susłygę śp. wielebnemu panu Świeborowskiemu [...] doszedł do zgody oraz uczynił wieczysty przyjacielski układ, w taki sposób że rzeczony sławetny Walenty Kędziora rzeczywiście i skutecznie zrzekł się tego długu, zapisanego na tymże ogrodzie przez Marcina Susłygę śp. wielebnemu panu Andrzejowi Świeborowskiemu, a także całego i wszelkiego swego prawa, które dowodzi mieć do rzeczonego długu, na rzecz wielebnego pana Kacpra, kanonika sandomierskiego i warszawskiego, [...] a także całe swoje prawo w ogólno-

\footnotetext{
${ }^{63}$ Ibid., s. 258.

${ }^{64}$ HAŁÓWNA, SENKOWSKI, op. cit., s. 301.

${ }^{65}$ Ibid., s. 317.

${ }^{66}$ Ibid., s. 317.

${ }^{67}$ Ibid., s. 378.

${ }^{68}$ Ibid., s. 369.

${ }^{69}$ Ibid., s. 222, 257.

${ }^{70}$ LESKIEWICZOWA, op. cit., s. 28.

${ }^{71}$ HAŁÓWNA, SENKOWSKI, op. cit., s. 222, 257.

72 Ibid., s. 319

73 Ibid, s. 319.

${ }^{74}$ Ibid., s. 327.

75 Ibid., s. 366.

${ }^{76}$ Ibid., s. 314.
} 
ści przelewa i wieczyście oraz na wieki zrzeka się go na rzecz rzeczonego wielebnego pana Kacpra. [...] Za ten dług oraz całe swoje prawo zeznający otrzymał od wielebnego pana Kacpra, kanonika sandomierskiego i warszawskiego, pełne i całkowite zadośćuczynienie, z którego to pełnego zadośćuczynienia kwituje tegoż wielebnego pana Kacpra oraz ogłasza go na wieczne czasy uwolnionym [...]"77. W dwa lata po tym wydarzeniu wojewodzina witebska Anna z Radziwiłłów Kiszczyna przejęła za długi należący do Kaspra Sadłochy dwór (curia) wraz z ogrodem zwanym „Suslidzinsky” oraz zabudowaniami pomocniczymi ${ }^{78}$. Całość położona była na przedmieściach Warszawy, między klasztorem Bernardynów a drogą ku Wiśle (późniejsza ulica Gnojowa, obecnie Bednarska) ${ }^{79}$.

Nazwa ogrodu, wzmiankowanego w wyżej wymienionym dokumencie - „Suslidzinsky" - nieodparcie kojarzy się z nazwą jednej z kamienic przyrynkowych Starej Warszawy (znanej też jako Falkiewiczowska lub Miodownikowska, położonej obok kamienicy Baryczków, na rogu Rynku i ulicy Krzywe Koło, obecnie noszącej nr $28^{80}$ ). W latach 1553-1566 została ona przebudowana przez ówczesnego właściciela, Marcina Susłygę (czy też Susligę) ${ }^{81}$, od którego nazwiska wzięła następnie swe miano (np. w 1574 r. została wzmiankowana jako „Szuslizynska”82). Kupiec Marcin Susyłga (Suliga) wywodził się z pochodzącej z Pułtuska bogatej rodziny mieszczańskiej, osiadłej w 1. połowie XVI w. w Warszawie ${ }^{83}$. Jego bratem był osławiony kanonik warszawski, Florian Susłyga ${ }^{84}$. W świetle dokumentu z 1570 r. Marcin Susłyga zabezpieczył nieokreślony bliżej dług, zaciągnięty u nieżyjącego już przy spisywaniu owego aktu kanonika warszawskiego Andrzeja Świeborowskiego na „ogrodzie bez budynków”, będącym widać własnością kupca. Prawa do rzeczonego długu od spadkobierców Świeborowskiego wykupił Kacper Sadłocha, który, będąc również kanonikiem warszawskim, zapewne znał dobrze całą sprawę

\footnotetext{
${ }^{77}$ AGAD, SW, 6, k. 416-417.

78 Jarosław Zawadzki podaje, że Kiszczyna zakupiła tę nieruchomość oraz że była to pierwsza tego typu transakcja magnaterii litewskiej w Warszawie; zob. Jarosław ZAWADZKI, „Anna z Radziwiłłów Kiszczyna, $2^{\circ}$ v $^{\circ}$ Sadowska burzliwe losy dziedziczki fortuny", [w:] Władza i prestiz. Magnateria Rzeczpospolitej w XVI-XVIII wieku, red. Jerzy URWANOWICZ, Ewa DUBAS-URWANOWICZ, Piotr GUZOWSKI, Białystok 2003, s. 386; id., „Dwory, zamki i pałace w siedzibach Kiszków herbu Dąbrowa do połowy XVII wieku”, Barok. Historia-Literatura-Sztuka, XIII:2006, nr 1, s. 98). O ile wypada zgodzić się z drugą częścią opinii Zawadzkiego, o tyle pierwsza wymaga sprostowania. Tekst dokumentu z 1572 r. jednoznacznie wskazuje bowiem, że powodem przekazania nieruchomości był zapis dłużny na sumę 1440 złotych, które Kacper Sadłocha był winien Annie. Do czasu spłaty długu przez Kaspra lub jego spadkobierców, Anna i jej spadkobiercy mogli swobodnie korzystać z nieruchomości; zob. k. AGAD, GW, 84A, k. 187. Sadłocha zastrzegł sobie jednak możliwość jej wykupu, pod warunkiem wszakże, że po spłacie długu wszystkie koszty poniesione przez Annę Radziwiłłównę (i jej spadkobierców) na wznoszenie nowych budynków na terenie nieruchomości zostaną jej zwrócone. Koszty te miały być udokumentowane w rejestrach, bez potwierdzania ich osobistą przysięgą, i powinny być zwrócone razem z sumą dłużną 1440 złotych.

${ }^{79}$ AGAD, GW, 84A, k. 186v, k. 201-201v.

${ }^{80}$ Katalog Zabytków Sztuki w Polsce, Seria Nowa, t. XI: Miasto Warszawa, cz. 1: Stare Miasto, red. Jerzy Z. ŁOZIŃSKI, Andrzej ROTTERMUND, Warszawa 1993, część tekstowa, s. 273.

${ }^{81}$ Ibid. s. 274.

${ }^{82}$ Por. AGAD, SW, 541, k. 67. Zbliżoną dzierżawczą nazwę (w 1586 r. wzmiankowana jako „Suslizinska”; zob. AGAD, SW, 538, k. 26) nosiła też inna kamienica przyrynkowa, obecnie zwana „Pod Fortuną”, znana także jako Dzianotowska lub Czempińska, znajdująca się po Stronie Barssa i nosząca nr 22. W latach 1541-1562 była ona własnością innych przedstawicieli rodziny Susłygów (Susligów), Stanisława i Jana; zob. Katalog Zabytków Sztuki w Polsce, Seria Nowa, t. XI: Miasto Warszawa..., s. 271.

${ }^{83}$ Por. Wanda SZANIAWSKA, „Droga do stołeczności i jej osiągnięcie”, [w:] Warszawa, jej dzieje i kultura, red. Aleksander GIEYSZTOR, Warszawa 1980, s. 59.

${ }^{84}$ Agnieszka BIEDRZYCKA, Zdzisław PIETRZYK, ,Suliga Florian (ok. 1520 - w lub po 1556)”, [w:] Polski Słownik Biograficzny, t. XLVI, red. Andrzej ROMANOWSKI, Warszawa-Kraków 2009-2010, s. 72.
} 


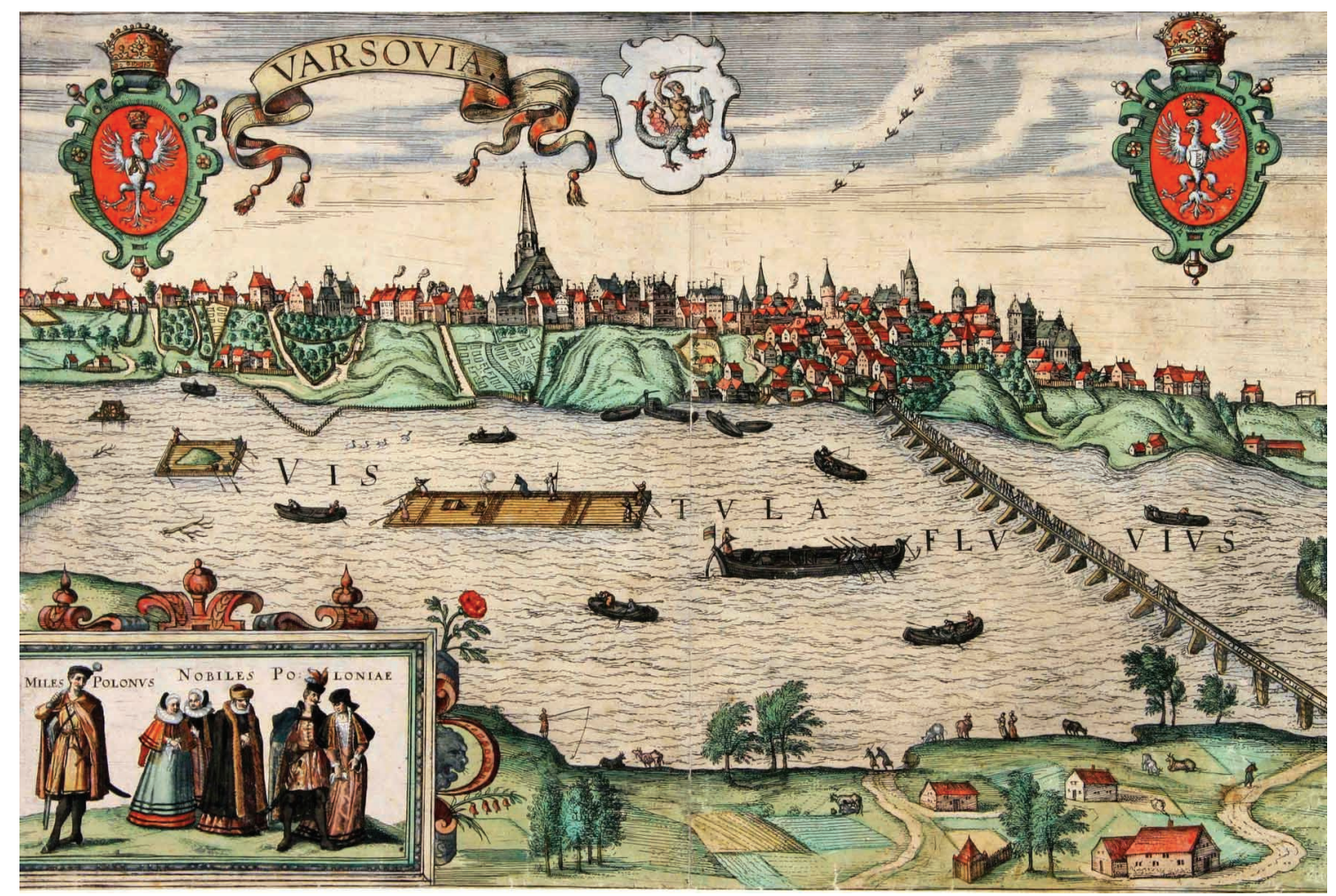

3. Widok Warszawy, rycina Abrahama Hogenberga wg rysunku Jacoba Hoefnagla z dzieła Georga Brauna i Fransa Hogenberga Civitates orbis terrarum collaborantibus Francisco Hogenbergio calcographo et Georgio Hoefnagiel, t. VI, Coloniae 1618. Muzeum Warszawy, nr inw. MHW 622/S

i mógł odpowiednio szybko zareagować. W ten sposób wszedł w posiadanie wspominanego już ogrodu, który w późniejszym czasie, podobnie jak dawna kamienica Susłygi, wciąż określany był dzierżawczym mianem „Suslidzinsky”. Na jego obszarze, zapewne wkrótce po omawianej transakcji, rozpoczął Kasper realizację swej siedziby, ukończonej jeszcze przed przejęciem całej nieruchomości przez Annę z Radziwiłłów Kiszczynę w 1572 r. Być może to właśnie ta inwestycja pochłonęła 4000 sztuk cegły z placu budowy zamku warszawskiego. Sadłocha zanotował bowiem w swym Szafunku..., że cegła ta nie została zwrócona właścicielowi, doktorowi Tomaszowi, gdyż „się pożyczyła"85. Bliżej nieokreśloną aktywność budowlaną Sadłochy potwierdzać też mogą pośrednio wzmianki w jego księdze rachunkowej, gdzie został wymieniony jako dostawca cegły, którą miał „z dawna nagotowaną do murowania na Kanonii”"86. Może to sugerować, że jeszcze przed rozpoczęciem przebudowy zamku planował on własną inwestycję, choć oczywiście równie dobrze mógł gromadzić niezbędny budulec w celach lepszego zaopatrzenia „fabryki” zamkowej, tym bardziej, że z jego zdobyciem bywały kłopoty.

Wzmianki źródłowe o warszawskiej siedzibie Sadłochy możemy połączyć z jej widokiem, uchwyconym na panoramie Warszawy, zawartej w VI tomie dzieła Georga Brauna i Fransa Hogenberga Civitates orbis terrarum collaborantibus Francisco Hogenbergio calcographo et Georgio Hoefnagiel, wydanego w 1618 r. w Kolonii, ale prezentującego realia z lat 80 . XVI w. ${ }^{87}$ (il. 3-4). Nota bene relikty opisywanej budowli zachowały się

\footnotetext{
${ }^{85}$ HAŁÓWNA, SENKOWSKI, op. cit., s. 319.

${ }^{86}$ Ibid., s. 222, 257.

${ }^{87}$ SZANIAWSKA, op. cit., s. 285.
} 
4. Wieżowa siedziba Kaspra Sadtochy, fragment ryciny z dzieła Georga Brauna i Fransa Hogenberga Civitates orbis terrarum collaborantibus Francisco Hogenbergio calcographo et Georgio Hoefnagiel, t. VI, Coloniae 1618. Muzeum Warszawy, nr inw. MHW 622/S

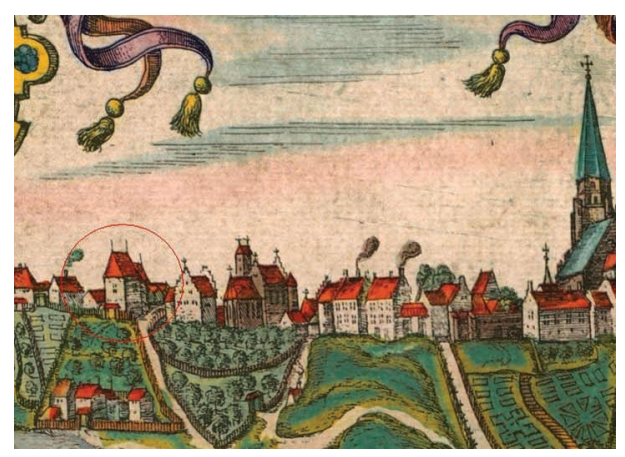

częściowo do dnia dzisiejszego. Jej mury są wciąż czytelne w piwnicach wschodniego skrzydła gmachu dawnego Towarzystwa Dobroczynności, stanowiącego obecnie siedzibę Caritas Archidiecezji Warszawskiej (il. 5). Przetrwało tam pomieszczenie (zapewne pierwotnie stanowiące parter siedziby Sadłochy), posadowione na rzucie zbliżonym do kwadratu, o centralnym filarze, wspierającym cztery pola sklepienia krzyżowego, wzmocnionego gurtami $^{88}$ (il. 6).

Na podstawie informacji źródłowych, ikonografii oraz zachowanych reliktów należy więc uznać, że siedziba Sadłochy była typową wieżą mieszkalną̨ ${ }^{89}$, przynajmniej trzykondygnacyjna, z przylegającą od północnego-zachodu, przekrytą dwuspadowym dachem dobudówka, mieszczącą najpewniej ciąg komunikacyjny (il. 7). Wieżę wieńczył czterospadowy dach, a nie, jak chcą niektórzy badacze, dwuspadowy z dwoma trójkątnymi szczytami $^{90}$. Wieża otoczona była ogrodem w którym stały (wzmiankowane w 1572 r.) zabudowania pomocnicze, całość zaś obwiedziona była płotem o drewnianych sztachetach.

Można domniemywać, że inwestycja Sadłochy była związana z nagromadzeniem przezeń w 2. połowie lat 60. XVI w. kilku beneficjów kościelnych (pleban osiecki, kanonik warszawski i sandomierski), jak też służbą Kaspra w kancelarii królewskiej jako sekretarza Zygmunta Augusta ${ }^{91}$. Nie bez znaczenia był też fakt rozpoczęcia nadzoru nad budowami

${ }^{88}$ Małgorzata ROZBICKA, Robert KUNKEL, Wojciech WÓŁKOWSKI, Interwencyjne badania architektoniczne w obrębie poludniowej części parteru i pierwszego piętra wschodniego skrzydła dawnego pałacu Kazanowskich, Warszawa 2007, s. 6 (maszynopis w archiwum Konserwatora Miasta Stołecznego Warszawy); Małgorzata ROZBICKA, Robert KUNKEL, Wojciech WÓŁKOWSKI, „Dzieje budowlane warszawskiego pałacu Adama Kazanowskiego w świetle badań architektonicznych", Ochrona Zabytków, 2017, nr 1, s. 11-13; Jakub LEWICKI, Joanna GIŻEJEWSKA, Wojciech PODSTOLSKI, Badania historyczne zespołu dawnego pałacu Adama Kazanowskiego, Warszawa 2007, s 9 (maszynopis udostępniony autorowi przez Łukasza Traczyka).

${ }^{89}$ Warto tu podkreślić, że proporcje budowli były tak wyraźnie wertykalne, że trudno zrozumieć określanie jej przez część badaczy mianem „dworu renesansowego” (zob. Zbigniew REWSKI, „Pałac Kazanowskich”, Stolica, 1954, nr 13, s. 12; Jolanta PUTKOWSKA, Architektura Warszawy XVII w., Warszawa 1991, s. 112) czy też „kamienicy” (zob. Adam MIŁOBĘDZKI, Architektura polska XVII wieku, Warszawa 1980, s. 204 (Dzieje sztuki polskiej, IV, 1), a nawet „renesansowej willi” (zob. Jarosław ZIELIŃSKI, Ulica Bednarska, Warszawa 1997, s. 8). Dopiero Jacek Gajewski prawidłowo określił siedzibę Sadłochy jako wieżę mieszkalną; zob. GAJEWSKI, op. cit., s. 89.

90 ZIELIŃSKI, Atlas dawnej architektury..., t. 7, s. 279; GAJEWSKI, op. cit., s. 98. Istnienia szczytów nie da się utrzymać nawet przy świadomości, że kolory ryciny załączonej do Civitates Orbis Terrarum ... zostały naniesione wtórnie. Wystarczy porównać dach wieży ze szczytami pobliskich budynków, a zwłaszcza klasztoru Bernardynów.

${ }^{91} \mathrm{Na}$ temat działalności fundacyjnej i horyzontów umysłowych grona sekretarzy królewskich zob. Andrzej WYCZAŃSKI, Między kulturq a polityka. Sekretarze królewscy Zygmunta Starego (1506-1548), Warszawa 1990, s. 96-131; Mirosław KOROLKO, Seminarium Rzeczpospolitej Królestwa Polskiego. Humaniści w kancelarii królewskiej Zygmunta Augusta, Warszawa 1991, 111-136; Leszek KAJZER, „Kaplice i wille. Rola sekretarzy królewskich w recepcji renesansu w Polsce (rozważania wokół ksiązki Andrzeja Wyczańskiego)", [w:] Archaeologia historica. Pisma wybrane, red. Lucyna DOMAŃSKA, Anna MARCINIAK-KAJZER, Aleksander ANDRZEJEWSKI, Warszawa 2014, s. 373-383. 

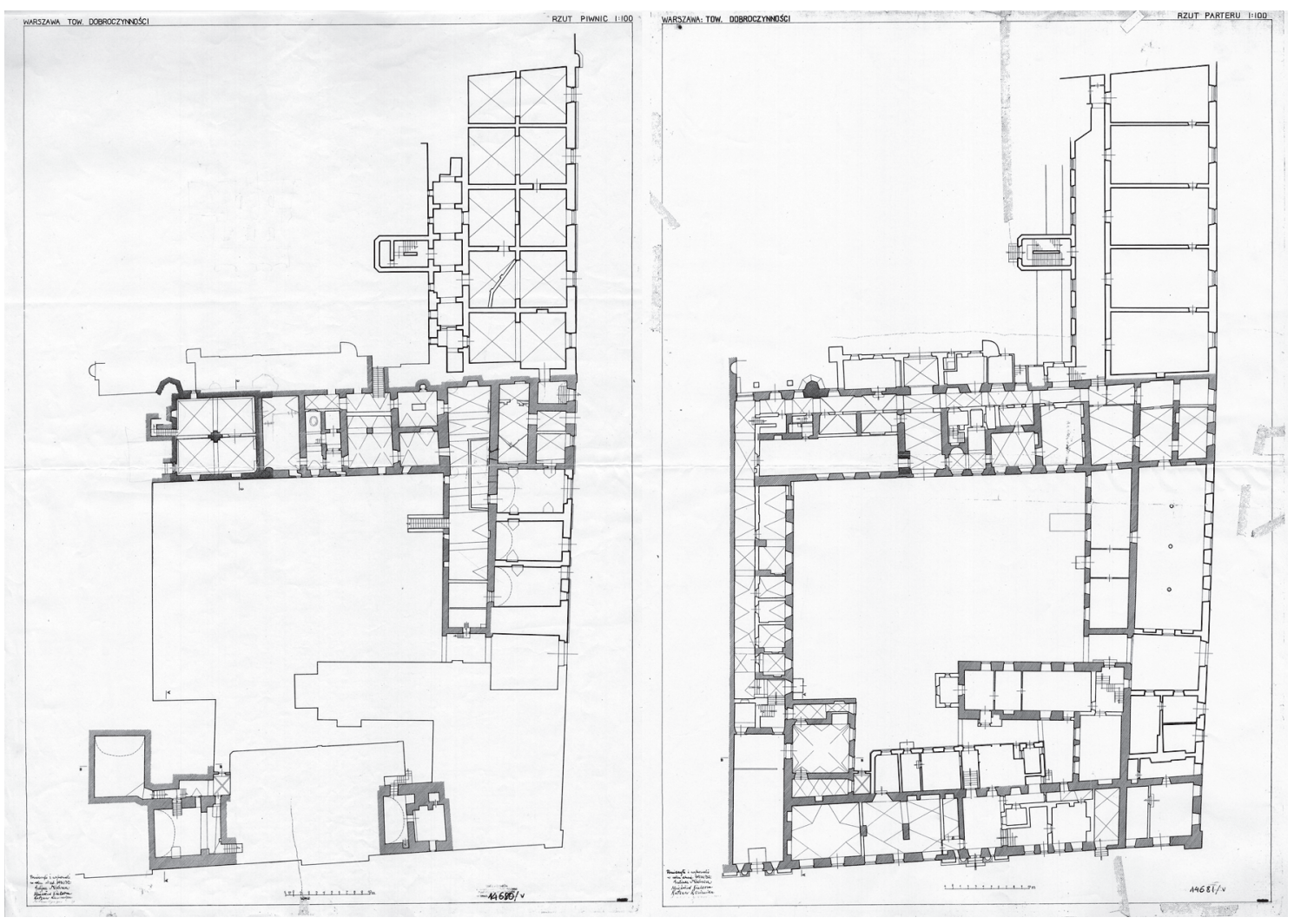

5. Rzut piwnic zespołu Caritas Archidiecezji Warszawskiej z zaznaczeniem murów z XVI (kolor czarny) i XVII w. (kolor szary). Rysunek pomiarowy wykonany w roku akademickim 1931-1932 przez studentów Politechniki Warszawskiej. Zbiory Zakładu Architektury Polskiej Wydziału Architektury Politechniki Warszawskiej

królewskimi. Niewatpliwie posiadanie reprezentacyjnej, wieżowej siedziby, w dodatku w tak prestiżowej lokalizacji, musiało dodawać znaczenia Sadłosze, który swą pozycję i majątek zawdzięczał głównie własnym talentom organizacyjnym i dyplomatycznym ${ }^{92}$. W 3. i 4. ćwierci XVI w. na budowę okazałej murowanej siedziby mogli sobie pozwolić zamożni posesjonaci (Alicja Szymczak do grona bogatej szlachty zaliczała posiadaczy od kilku do kilkunastu wsi, piastujących najczęściej dodatkowo urzędy ziemskie ${ }^{93}$ ). Sąsiadami Kaspra byli przedstawiciele elity szlachty mazowieckiej, m.in. Radziejowscy, Oborscy, kasztelan płocki i wojewoda rawski Anzelm Gostomski, a także możnowładcy koronni, jak wojewoda krakowski Stanisław Tęczyński, który już w 1557 r. pozyskał działkę przy drodze ku św. Krzyżowi ${ }^{94}$. Wieża mieszkalna stanowiła więc dla Sadłochy niejako legitymizację funkcjonowania w obrębie dopiero co osiagniętej elity, jak też widomy dowód szlachetnego pochodzenia, które, nota bene, mogło być przez niektórych negowane. Wprawdzie wyniki badań Leszka Belzyta wskazują, że w omawianym okresie nie dochodziło jeszcze do wyraźnego piętnowania szlachty przyjmującej prawo miejskie, jednocześnie jednak badacz ten zaznacza, że miejscy szlachcice ,usiłowali za wszelką cenę utrzymać swój dotychczasowy status szlachecki"95.

\footnotetext{
${ }^{92}$ Na temat uwarunkowań społecznych i znaczeń symbolicznych siedziby Sadłochy zob. LASEK, TRACZYK, op. cit., s. $129-149$.

${ }^{93}$ Alicja SZYMCZAK, Szlachta sieradzka w XV w. Magnifici et generosi, Łódź 1999, s. 12.

${ }^{94}$ SZANIAWSKA, op. cit., s. 292.

${ }^{95}$ BELZYT, op. cit., s. 10.
} 


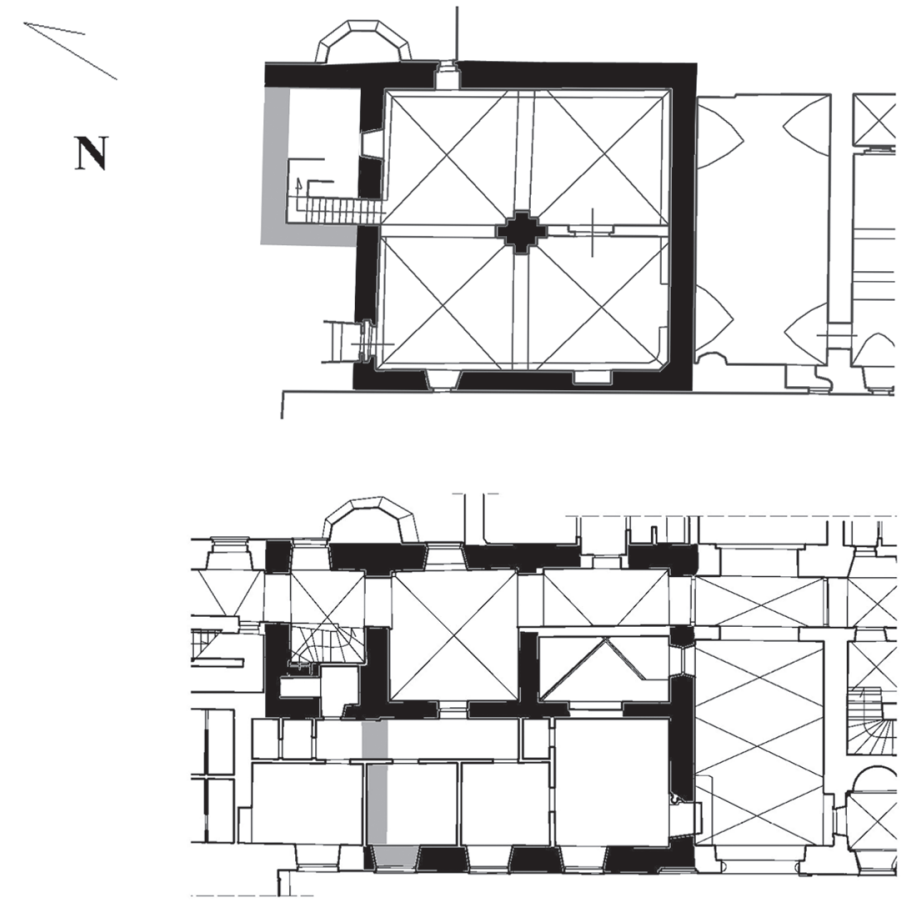

6. Fragment rzutu piwnic, przyziemia i piętra zespolu

Caritas Archidiecezji

Warszawskiej

z zaznaczeniem murów wieży

Kaspra Sadlochy (mury

istniejace - kolor czarny,

mury rekonstruowane kolor szary).

Oprac. Pawet Rajski

na podstawie rysunku pomiarowego z lat 1931-

1932 oraz wyników badań

Matgorzaty Rozbickiej,

Roberta Kunkela

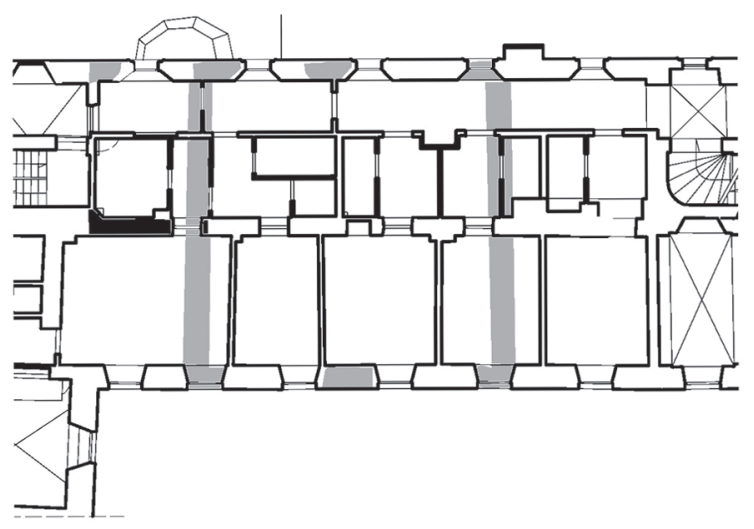

i Wojciecha Wótkowskiego

Casus Sadłochy pokazuje, że w przypadku ludzi w pierwszym pokoleniu wchodzących w krag elity, szybka kariera i dobra sytuacja ekonomiczna mogły łatwo ulec zahamowaniu. Śmierć monarchy w 1572 r. pozostawiła kanonika z długami, których nie był w stanie spłacić. Niestety nie wiemy, kiedy Sadłocha zadłużył się u wojewodziny witebskiej, ani na co konkretnie przeznaczył uzyskaną pożyczkę. Wysoka kwota zapisu dłużnego (1440 złotych polskich), którego zabezpieczeniem była okazała siedziba wraz z ogrodem, sugeruje, że suma ta musiała być przeznaczona na znaczną inwestycję, być może zakup nieruchomości. Jacek Gajewski jako przyczynę zadłużenia kanonika wskazuje zaciągnięcie przez Sadłochęjeszcze za życia króla pożyczek dla dokończenia warszawskich inwestycji Zygmunta 


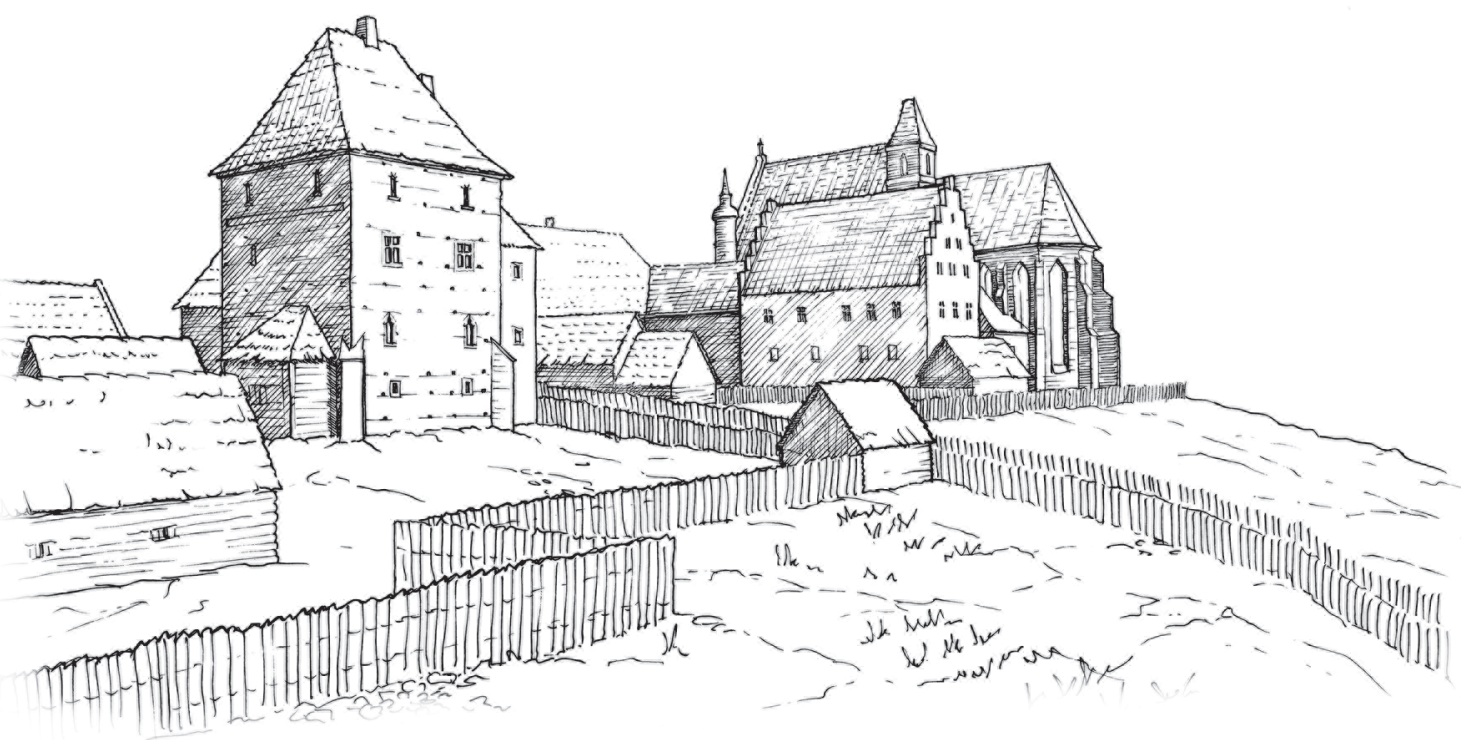

7. Próba rekonstrukcji bryły siedziby Kaspra Sadłochy, widok od południowego wschodu. Oprac. Pawet Rajski

Augusta ${ }^{96}$. Istotnie, wpisy z księgi rachunkowej Stanisława Fogelwedra za lata 1570-1571 ujawniają, że Zygmunt August borykał się z brakiem gotówki, uciekając się do kredytów kupieckich, pożyczek pod zastaw nieruchomości czy dzierżawy królewszczyzn ${ }^{97}$. W $1576 \mathrm{r}$. Sadłocha otrzymał ze skarbca koronnego pieniądze za prace przy budowie mostu, nie wiadomo jednak, czy był to zwrot sum pożyczonych wcześniej monarsze, czy też opłata za nadzór budowlany nad realizacją w latach $1575-1576^{98}$. Co więcej, w rachunkach Stanisława Fogelwedra, sekretarza prywatnego króla ${ }^{99}$, nie ma wzmianki o podobnej pożyczce $^{100}$, choć oczywiście nie można całkowicie wykluczyć, że Sadłocha takowej królowi jednak udzielił.

Przyczyny finansowego upadku Sadłochy można upatrywać również w przeszacowaniu własnych możliwości inwestycyjnych. Jak bowiem zauważył Leszek Kajzer, w 3. ćwierci XVI w. wzniesienie murowanego dworu wiązało się z koniecznością wydania 3000-4000 tysięcy złotych polskich ${ }^{101}$. Na 2000 złotych polskich budowniczy Benedykt z Opola wycenił w 1568 r. wzniesienie murowanego dworu dla kasztelana brzeskiego Mikołaja Boruckiego ${ }^{102}$. W tym samym czasie dochód $\mathrm{z}$ jednego łana gruntów folwarcznych w Wielkopolsce sięgał od 35 do 55 złotych polskich rocznie ${ }^{103}$. Tymczasem Sadłocha jako pisarz kancelarii królewskiej otrzymywał zaledwie 100 złotych polskich rocznie.

\footnotetext{
${ }^{96}$ GAJEWSKI, op. cit., s. 92.

${ }^{97}$ Np. w 1570 r. król oddał w dzierżawę Jakubowi Zaleskiemu, pisarzowi skarbu nadwornego, tenutę Piaseczno, z zastrzeżeniem, że należność dzierżawna w gotówce ma być oddawana Kasprowi Sadłosze na budowę zamku w Warszawie; zob. KARWASIŃSKA, op. cit., s. 211.

${ }^{98}$ RUTKOWSKI, SOŁTAN, op. cit., s. 281.

99 Zob. Marek FERENC, Dwór Zygmunta Augusta, Kraków 1998, s. 29.

${ }^{100}$ KARWASIŃSKA, op. cit., s. 197-214.

${ }^{101}$ Por. Leszek KAJZER, Dwory w Polsce. Od średniowiecza do współczesności, Warszawa 2010, s. 92-93.

102 Zbigniew REWSKI, Majstersztyki krakowskiego cechu murarzy i kamieniarzy XVI-XIX wieku, Wrocław 1954, s. 96.

103 KAJZER, „Kaplice i wille...”, s. 374.
} 
Po objęciu funkcji sekretarza królewskiego jego dochody zapewne wzrosły. Wedle Andrzeja Wyczańskiego średni dochód sekretarzy królewskich wynosił ok. 500-700 złotych polskich rocznie ${ }^{104}$. Ową kwotę w większości przypadków stanowiły zyski z różnych beneficjów. Nie inaczej było w przypadku Kaspra Sadłochy, który np. w kapitule kolegiackiej w Warszawie uposażony był dziesięcinami ze wsi Kossowo koło Płocka (rocznie po 8 groszy z łanu na 55 łanach kmiecych) ${ }^{105}$. Pozostawanie w służbie monarszej łączyło się jednak nie tylko z przywilejami i uposażeniami, ale też wydatkami ${ }^{106}$, które trzeba było pokrywać z własnej kieszeni ${ }^{107}$. Przedstawiciele rodzin możnowładczych byli na takie ekspensa przygotowani, posiadali bowiem własne rozległe majątki ziemskie, które w razie potrzeby mogli sprzedać lub zastawić. Kasper Sadłocha, jako szlachcic miejski, nie posiadający innych wpływów poza uposażeniami płynącymi z racji piastowanych stanowisk czy godności kościelnych, nie miał takich możliwości. Zapewne zaciagając długi liczył na swoją uprzywilejowaną pozycję jako zarządcy długotrwałych i prestiżowych budów królewskich. Po zgonie Zygmunta Augusta jego wpływy na dworze, a więc także perspektywy dalszej kariery stanęły pod znakiem zapytania, w związku z czym wojewodzina witebska mogła poczuć się zaniepokojona o zwrot pożyczonej kwoty ${ }^{108}$. Zapewne też niechętnym okiem patrzyła na szybką karierę miernie urodzonego Sadłochy. Kasper zaś, nie dysponując jeszcze, jak w późniejszych latach, znaczniejszymi oszczędnościami, nie był w stanie wyłożyć odpowiedniej ilości gotówki i popadł w tarapaty finansowe. Niemniej w akcie rezygnacji z dworu i ogrodu zastrzegł sobie i swym ewentualnym spadkobiercom możliwość ich wykupu ${ }^{109}$, co pokazuje, że traktował całą sytuację jako przejściową i liczył się z możliwością odzyskania utraconej nieruchomości. Nie doszło do tego zapewne ze względu na znalezienie przez Sadłochę nowej lokalizacji dla swej siedziby.

Chwilowe kłopoty i strata dworu istotnie nie zdołały zatrzymać kariery ambitnego kanonika na dworze królewskim. Kasper cieszył się bowiem łaskami i zaufaniem Anny Jagiellonki, później zaś także jej męża, Stefana Batorego. Jego kontakty z Anną mogły zostać łatwo zadzierzgnięte jeszcze podczas jej pobytu z matką na Mazowszu. Po śmierci Zygmunta Augusta z polecenia jego siostry i spadkobierczyni prowadził nadzór nad budową mostu warszawskiego aż do jego ukończenia ${ }^{110}$, zaś po jej ślubie z Batorym został sekretarzem królewskim ${ }^{111}$, pozostającym jednak w dyspozycji królowej ${ }^{112}$. Jak podkreśla Maria

\footnotetext{
${ }^{104}$ WYCZAŃSKI, op. cit., s. 95.

${ }^{105}$ KRÓLIK, op. cit., s. 85.

106 Jak choćby utrzymywanie pisarza dla prowadzenia ksiąg, gdyż Sadłocha nie pisał swego Szafunku... osobiście; zob. KARWASIŃSKA, op. cit., s. 192.

107 Antoni GĄSIOROWSKI, „Rotacja elity władzy w średniowiecznej Polsce”, [w:] Społeczeństwo Polski średniowiecznej, red. Stefan Krzysztof KUCZYŃSKI, t. 1, Warszawa 1981, s. 264-290.

108 Jarosław Zawadzki, który jako pierwszy dostrzegł konieczność badań działań gospodarczych Anny, zauważył, że była ona niezwykle energiczną i zaradną osoba, m.in. prowadzącą przemyślaną politykę zakupu nowych dóbr, jak też dbająca o ich właściwe zagospodarowanie (np. była prekursorką przeprowadzenia w dobrach prywatnych Wielkiego Księstwa pomiary włócznej); zob. ZAWADZKI, op. cit., s. 383-384.

109 Por. przypis. 78.

110 Wacław STERNER, Mosty Warszawy, Warszawa 1960, s. 31.

${ }^{111}$ Leszek KIENIEWICZ, „Sekretariat Stefana Batorego. Zbiorowość i kariery sekretarzy królewskich”, [w:] Społeczeństwo Staropolskie, t. IV, red. Anna IZYDORCZYK, Andrzej WYCZAŃSKI, Warszawa 1986, s. 65.

$112 \mathrm{Z}$ takim tytułem figuruje kilkakrotnie w korespondencji nuncjusza Albertiego Bolognettiego z lat 1581-1584; zob. „Alberti Bolognetti nuntii apostolicii in Polonia epistolae et acta 1581-1585, pars I, 1581-1582, [w:] Monumenta Poloniae Vaticana, t. V, wyd. Edward KUNTZE, Czesław NANKE, Cracovia 1923-1933, nr 174, s. 177, nr 199, s. 207, nr 233, s. 247, nr 374, s. 389; ,Alberti Bolognetti nuntii apostolicii in Polonia epistolarum et actorum, pars III, fasc. I (1584)", [w:] Monumenta Poloniae Vaticana, t. VII, edidit Edward KUNTZE, Kraków 1939-1948, nr 335, s. 503.
} 
Bogucka, Anna Jagiellonka umiała zabiegać o wakanse i urzędy dla swych sług i dworzan $^{113}$. Za jej wstawiennictwem Kasper Sadłocha otrzymał też w 1573 r. plebanię latowicką, którą w 1576 zamienił na intratniejsze probostwo garwolińskie ${ }^{114}$. W 1577 r. został scholastykiem w kolegiackiej kapitule warszawskiej, na którym to stanowisku zasłużył się dbaniem o uposażenia nauczycieli funkcjonującej przy kolegiacie szkoły ${ }^{115}$. Ustanowił także w kolegiacie altarię pod wezwaniem Męki Pańskiej, której użytkownikami byli rektorzy szkoły. W 1579 r. został plebanem w Bielsku na Podlasiu ${ }^{116}$. Jednocześnie świadczył różne usługi królowi Stefanowi Batoremu, m.in. godząc spór między starostą osieckim a poddanymi o wymiar pańszczyzny ${ }^{117}$. Także doświadczenie budowlane Sadłochy było najwyraźniej wciąż cenione i pamiętane, ponieważ monarcha wyznaczył go do zespołu rozpatrującego skargę rady warszawskiej o bezprawne wzniesienie domów przy murze miejskim ${ }^{118}$. W $1580 \mathrm{r}$. Batory nakazał Michałowi Maleskowskiemu, wielkorządcy zamku wawelskiego, spławić Wisłą do Warszawy 200 belek, 7 kop tarcic oraz 800 kop gontów do odbudowy szpitala Świętej Trójcy ${ }^{119}$. Na miejscu materiały te miały być przekazane na ręce Kaspra Sadłochy, co wskazuje, że najpewniej sprawował on nadzór nad tą inwestycją. Co więcej, w 1581 r. otrzymał ponad 900 złotych polskich z żup krakowskich na budowę szpitala dla wysłużonych żołnierzy, nad którą to realizacją także miał sprawować nadzór ${ }^{120}$.

W tym samym czasie ambitny kanonik rozwinął szeroką działalność gospodarczą, która rychło pozwoliła mu osiagnnąć znaczny majątek. Co znamienne, specjalizował się w transakcjach z dobrze sobie znanej dziedziny - nieruchomości. W 1579 r. krawiec i obywatel Warszawy Jan Lysz zrzekł się na rzecz Sadłochy swego ogrodu, zwanego Lyszczowski, położonego na przedmieściu warszawskim, między ogrodami niejakich Kępnowskiego i Drewnowskiego, ,za sumę zawartą i wyrażoną na piśmie w kontrakcie sprzedaży w księgach radzieckich warszawskich [...]"121. W 1582 r. Abraham Hegner, mieszczanin i kupiec warszawski zeznał, że sprzedał Sadłosze swój spichlerz wraz z działką, położony przy ulicy Tylnej, pomiędzy działkami Stanisława Kępczyka z jednej, z drugiej zaś właśnie Sadłochy, ,za sumę sześćdziesięciu pięciu złotych polskich, liczonych po trzydzieści groszy polskich [...]"122. W roku następnym natrafiamy na transakcję między Sadłochą a Hanuszem Jenki, lekarzem i mieszczaninem warszawskim, który zrzekł się "swego własnego ogrodu, zwanego Lyszczowski, położonego i leżącego na przedmieściu warszawskim, pomiędzy z obu stron ogrodami wielebnych panów Patrycjusza, doktora świętej teologii, oraz Kacpra Sadłochy, na rzecz tegoż wymienionego wielebnego pana Kacpra Sadłochy, scholastyka warszawskiego i sekretarza królowej, za sumę zawartą i wyrażoną na piśmie w kontrakcie sprzedaży w księgach radzieckich warszawskich

\footnotetext{
113 Maria BOGUCKA, Anna Jagiellonka, Wrocław 2009, s. 174-175.

${ }^{114}$ Lustracja województwa mazowieckiego 1565, część I. Indeksy do części I i II, oprac. Irena GIEYSZTOROWA, Kazimierz PACUSKI, Alina WAWRZYŃCZYK, Anna ŻABOKLICKA, , Warszawa 1967, s. 34 (Lustracje dóbr królewskich XVI-XVIII wieku. Mazowsze).

115 KRÓLIK, op. cit. s. 48.

${ }^{116}$ Lustracja województwa mazowieckiego 1565 ..., s. 34.

117 LESKIEWICZOWA, op. cit., s. 38.

118 Aleksander WEJNERT, Starożytności Warszawskie, t. VI, Warszawa 1858, s. 255-259.

119 AGAD, ASK, Dz.VI, Księgi asygnat, 3, k. 79 (dawniej 131).

${ }^{120}$ Księgi podskarbińnkie z czasów Stefana Batorego 1576-1586, wyd. Adolf PAWIŃSKI, Warszawa 1881, s. 38,55 (Źródła Dziejowe, IX/II).

${ }^{121}$ AGAD, SW, 541, k. 131v-132.

122 Ibid., k. 195-195v.
} 
[...]"123. Prócz inwestycji w nieruchomości Sadłocha pożyczał też często pieniądze potrzebującym gotówki przedstawicielom stanu szlacheckiego. W $1581 \mathrm{r}$. skwitował Jacka Młodziejewskiego, skarbnika dworu Królestwa, z sumy 900 złotych węgierskich ${ }^{124}$. Z kolei w 1588 r. zeznał, że „kwituje i wieczyście oswobadza wielmożnego Mikołaja Kiszkę z Ciechanowca, starostę drohiczynskiego, [...] z 1707 złotych polskich, zapisanych w aktach drohiczyńskich, [...] a to względem nowego i późniejszego zapisu, uczynionego również w aktach grodzkich drohiczyńskich na sumę 1900 złotych polskich [...]"125. W 1595 r. Wojciech, syn nieżyjącego już Wawrzyńca Świnoleskiego z powiatu świeckiego, ,zeznał, że [...] zapisuje i zobowiązuje się, iż winien jest [...] sumę czterech tysięcy złotych polskich, licząc każdy złoty za trzydzieści groszy polskich, [...] na najbliższe święto Pięćdziesiątnicy zapłacić [...] wielebnemu Kacprowi Sadłosze, prepozytowi warszawskiemu [...]"126. W następnym roku Sadłocha skwitował owego Wojciecha Świnoleskiego z pożyczonej mu sumy ${ }^{127}$. Jak wkrótce zobaczymy, osoba ta odegrała u schyłku życia sędziwego prepozyta znaczną rolę. W roku 1596 „szlachetny Tomasz Chajecki, syn śp. Antoniego Chajeckiego z ziemi kamienieckiej województwa mazowieckiego", pożyczył od Kaspra znacznie mniejszą, bo wynoszącą zaledwie 100 złotych polskich, sumę $^{128}$. Jeszcze w 1599 r. stojący już u kresu swych dni prepozyt warszawski pożyczył Janowi Glinieckiemu, synowi Wojciecha Glinieckiego, notariusza ziemskiego czerskiego, dziedzica na Glinkach, ,sumę 100 złotych węgierskich w złocie czystej i sprawiedliwej wagi, licząc każdy złoty węgierski jako 58 groszy polskich [...]"129. Niekiedy miał Kasper kłopot z odzyskaniem długu. W środę po święcie Pięćdziesiątnicy roku Pańskiego 1584 w dworze królewskim warszawskim stawił się ,wielebny pan Kacper Sadłocha, scholastyk warszawski”, który „tak jak w niedzielę i w poniedziałek obecnego święta Pięćdziesiątnicy, tak też w dniu dzisiejszym, tegoż święta Pięćdziesiątnicy już ostatnim, [...] oczekiwał od urodzonego Mikołaja Mniszka z Wielkich Kuńczyc, starosty łukowskiego, [...] złożenia sumy trzech tysięcy złotych pieniądza polskiego, zapisanej mu przez niego na święto Pięćdziesiątnicy w roku przeszłym [?] i na mocy odroczenia do dnia dzisiejszego, uczynionego przez tegoż wielebnego Kacpra temuż staroście łukowskiemu mającej być wypłacona, [...] pozostając w gotowości przyjęcia tych pieniędzy [...]. Ponieważ zaś tenże sam urodzony Mikołaj Mniszek nie stawił się, tedy sam wielebny Kacper Sadłocha [...] złożył oświadczenie[...] o swojej obecności, a także by zapisać przeciwko temuż Mikołajowi Mniszkowi jego niestawienie się, [...] prosząc, aby pozwolono, by jego oświadczenie i jego obecność zostały przyjęte i zapisane, co uzyskał od niniejszego urzędu"130. Zapewne po powyższej skardze obie strony zawarły ugodę, bowiem już w następnym roku „Kacper Sadłocha, scholastyk warszawski, prepozyt bielski i sekretarz Jej Królewskiej Wysokości, [...] zeznał, że na prośbę urodzonego Mikołaja Mniszka, starosty łukowskiego etc., [...] odracza [...] odtąd do święta św. Jana Chrzciciela w roku przyszłym [...] zapłatę sumy trzech tysięcy złotych polskich, licząc po 30 groszy [...]"131.

\footnotetext{
123 AGAD, SW, 541, k. 206v.

${ }^{124} \mathrm{GW}$, donationum, 3, k. 488v.

${ }^{125} \mathrm{GW}$, donationum, 13, s. 280.

${ }^{126} \mathrm{GW}$, donationum, 19, k. 757-759v.

$127 \mathrm{GW}$, donationum, 20, s. 344

${ }^{128}$ Ibid., s. 981-982.

${ }^{129} \mathrm{GW}$, donationum, 25, s. 509-510.

${ }^{130} \mathrm{GW}$, donationum, 8, s. 1688-1689.

${ }^{131} \mathrm{GW}$, donationum, 9, s. 312.
} 
Sadłocha, przeżywający najwyraźniej za czasów Anny Jagiellonki okres niezwykłej pomyślności ekonomicznej, nie wyzbył się marzeń o posiadaniu własnej siedziby. Z akt Metryki Koronnej dowiadujemy się, że w 1590 r. zajmował dom kapituły warszawskiej, położony poza murami Warszawy ${ }^{132}$. Z kolei 1 maja 1593 r. z nakazu Zygmunta III Wazy wpisano do akt Metryki, że „,czcigodny Kacper Sadłocha, prepozyt warszawski, sekretarz Jej Królewskiej Mości, naszej umiłowanej ciotki, [...] zeznał, że [...] sprzedał, odstąpił i faktycznie zrzekł się [...] na rzecz przewielebnego ojca w Chrystusie, pana Wojciecha Baranowskiego, biskupa płockiego, [...] swego własnego gruntu i dworu, uzyskanego prawomocnie, wieczystym tytułem prawnym, od różnych osób, wystawionego własnym sumptem, wraz ze wszystkimi budynkami, budowlami, ogrodami i innymi dogodnościami, w Warszawie na przedmieściu krakowskim, pomiędzy domami Zygmuntowskim z jednej strony oraz urodzonego Jana Leśniowolskiego, kasztelana czerskiego i starosty parnawskiego, z drugiej strony, z tyłu zaś Walbachowskiego, położonego na ulicy zwanej Kozią, a także pewnej cząstki czy też działu gruntu wraz z budynkami, sąsiadującego z rzeczonym dworem, [własności] dzieci szlachetnego Stanisława Łączyńskiego, spłodzonych ze szlachetną śp. Dorota, jego żoną, oraz szlachetnej Katarzyny, żony szlachetnego Wojciecha Świnoleskiego, [...] za sumę trzech tysięcy złotych, licząc każdy złoty po trzydzieści groszy polskich"133. Nie wiemy, niestety, kiedy doszło do kreacji owego dworu, ani też nie mamy informacji o jego strukturze i budulcu. Pokaźna kwota, za jaką Sadłocha sprzedał swą siedzibę biskupowi płockiemu Wojciechowi Baranowskiemu, wskazywałaby, że ów dwór mógł być murowany ${ }^{134}$. Jest to jednak jedynie hipoteza, którą powinny zweryfikować badania archeologiczno-architektoniczne pałacu Prymasowskiego, nie wiemy bowiem, jaka część kwoty transakcji obejmowała sam gmach dworu, a jaka działkę z ogrodem i innymi zabudowaniami.

Sprzedaż dworu biskupowi Baranowskiemu sprawiła, że sędziwy już Kasper Sadłocha znowu pozostał bez własnej siedziby. Jednocześnie jednak posiadał gotówkę, którą mógł spożytkować na dalsze inwestycje. Analiza materiałów źródłowych wskazuje, że pod koniec życia był właścicielem przynajmniej dwóch nieruchomości. Na początku nowego, XVII stulecia schorowany Sadłocha, najwyraźniej w poczuciu zbliżającej się śmierci, począł czynić dyspozycje majątkowe wobec swych spadkobierców. W 1602 r. odstąpił dzierżoną przez siebie $\mathrm{w}$ dożywocie wieś Chrosna z przyległymi miejscowościami swemu siostrzeńcowi, Adamowi Branwickiemu ${ }^{135}$. W tymże samym roku do ksiąg miejskich Starej Warszawy wpisano, że ksiądz Kasper Sadłocha, prepozyt kolegiaty św. Jana, „chociaż chory na ciele, jednak zdrowy na umyśle” darował swą kamienicę, położoną przy ulicy Świętojańskiej, między kamienicami należącymi do biskupa poznańskiego oraz sukcesorów kupca warszawskiego, Abrahama Hegnera, wójtowi bielskiemu Stanisławowi Łączyńskiemu oraz Wojciechowi Świnoleskiemu, ,swoim powinowatym i przyjaciołom oraz prawowitym dziedzicom i następcom"136. Dla omawianej problematyki niezwykle

\footnotetext{
${ }^{132}$ Księga wpisów podkanclerzego Wojciecha Baranowskiego z okresu marzec 1588-grudzień 1590 MK 135 z Archiwum Głównego Akt Dawnych w Warszawie, oprac. Wojciech KRAWCZUK, Michał KULECKI, Warszawa 2010, nr 1085, s. 392 (Sumariusz Metryki Koronnej, Seria Nowa, IV, red. Wojciech KRAWCZUK).

${ }^{133}$ AGAD, MK, 138, k. 79-80 ; zob. też: PUTKOWSKA, op. cit., s. 121. Autor składa Jolancie Putkowskiej serdeczne podziękowania za konsultacje udzielone w sprawie tychże archiwaliów.

${ }^{134}$ Skupował on okoliczne działki pod budowę swego pałacu, zapisanego następnie kapitule gnieźnieńskiej z przeznaczeniem na pałac arcybiskupów; zob. PUTKOWSKA, op. cit., s. 121.

135 AGAD, MK, t. 147, k. 206v-207.

${ }^{136}$ AGAD, SW, 16, k. 61-62v.
} 
istotnym jest, że do owej donacji doszło „we dworze wielebnego pana Kacpra Sadłochy, [...] położonym i znajdującym się poza murami miasta, $\mathrm{w}$ dolinie przed fosą, pomiędzy domami czy też dworami wielmożnego pana Stanisława z Mińska, wojewody łęczyckiego, starosty płockiego itd., z jednej strony, oraz wdowy po urodzonym śp. panu Wawrzyńcu Laskowskim, notariuszu ziemskim warszawskim, z drugiej strony [...]"137. Mamy więc pewną informację o kolejnych siedzibach Kaspra Sadłochy, jednej położonej extra muros, drugiej zaś intra muros Starej Warszawy, w prestiżowej lokalizacji blisko kościoła kolegiackiego. Zastanawiające jest także, że w działalności majątkowej i życiu osobistym Kaspra ponownie pojawia się tu ów Wojciech Świnoleski, w dodatku zwany „powinowatym i prawowitym dziedzicem" Sadłochy. O człowieku tym nie zachowało się wiele informacji. Brak wzmianki o nim w herbarzu Bartosza Paprockiego ${ }^{138}$. Jego gniazdem rodowym było zapewne Świnolesie, majątek położony koło Świecia ${ }^{139}$. Był synem Wawrzyńca Świnoleskiego, nieżyjącego już w 1595 r. ${ }^{140} \mathrm{~W}$ akcie sprzedaży swego dworu biskupowi płockiemu Andrzejowi Baranowskiemu Sadłocha reprezentował też interesy kilku właścicieli drobniejszych działek, w tym m.in. nieznanej bliżej Katarzyny, żony Wojciecha Świnoleskiego ${ }^{141}$. Relacje tych dwojga z kanonikiem Sadłochą, zarówno osobiste, jak i majątkowe musiały być bliskie, skoro Świnoleski zrzekł się na rzecz Sadłochy wsi Drozdy. Zapewne chodzi o osadę nieopodal Tarczyna, co pokazuje, że Wojciech rozszerzył swe dobra o posiadłości w województwie mazowieckim. Ustalenie, jakie związki rodzinne łączyły Sadłochę i Świnoleskiego, jak też kim był i jaką rolę pełnił w ówczesnej Warszawie ten ostatni, wykracza poza ramy tematyczne niniejszego tekstu i winno stać się przedmiotem badań historyków-genealogów.

U schyłku życia Kasper Sadłocha zdecydował także o zmianie statusu z szlachcica miejskiego na ziemianina. Już od 1594 r., dzięki staraniom Anny Jagiellonki, dzierżył w dożywocie zarząd nad wsią Chrosna z folwarkiem i wójtostwem, a także wsiami Człowiekówka, Karpica, jak też młynem „Paluch” koło wsi Lubica ${ }^{142}$. Dożywotnio trzymał też wieś Rudnik w starostwie osieckim, nadaną mu przez starostę łukowskiego i osieckiego, Mikołaja Mniszcha ${ }^{143}$. W 1596 r. woźny generalny Królestwa, Jakub Sokołek z Drozdów, wraz z Jakubem Biernackim i Andrzejem Kamińskim ,zeznali, że wielebnego Kacpra Sadłochę, prepozyta warszawskiego, sekretarza starszej królowej, [...] w dobra, mianowicie całą wieś Drozdy, przez urodzonego Wojciecha Świnoleskiego [...] zrzeczoną wieczyście na drodze nieodwołalnej donacji, wwiązali [...]"144. Być może na decyzję sędziwego już duchownego wpłynęły nasilające się u schyłku XVI w. tendencje do coraz ostrzejszej krytyki przez szlachtę tych jej przedstawicieli, którzy nie posiadając dóbr ziemskich, szukali zajęcia w mieście, podlegali prawu miejskiemu bądź też wykonywali miejskie zawody.

\footnotetext{
${ }^{137}$ Ibid., k. 61.

${ }^{138}$ Bartosz PAPROCKI, Herby rycerstwa polskiego, wyd. Kazimierz Józef TUROWSKI, Kraków 1858.

139 Józef KRZEPELA, Rody ziem pruskich, Kraków 1927, s. 95. Inna gałąź rodu zamieszkiwała najpewniej ziemię nurska, jeszcze w 1674 r. występował tam Jakub Świnołęski; zob. Kasper NIESIECKI, Herbarz Polski, t. VIII, Lipsk 1841, s. 583. Badań nad pochodzeniem rodziny nie ułatwiają różne formy zapisu nazwiska rodowego: „Świnoleski”, „Szwinolewski”, „Świnołęski”;zob. KRZEPELA, op. cit., s. 95.

$140 \mathrm{GW}$, donationum, 19, k. 757-759v.

${ }^{141}$ AGAD, MK, 138, k. 80.

142 AGAD, MK, 148, k. 198-199.

${ }^{143}$ Księga wpisów podkanclerzego Jana Tarnowskiego MK 139 z Archiwum Głównego Akt Dawnych w Warszawie 1595, oprac. Krzysztof CHŁAPOWSKI, Warszawa-Bellerive sur Allier 2016, nr 85, s. 49 (Sumariusz Metryki Koronnej, Seria Nowa, VIII, red. Krzysztof CHŁAPOWSKI).

${ }^{144} \mathrm{GW}$, donationum, 19, k. 1409.
} 
Groziło to utratą szlachectwa, a na to najwyraźniej Sadłocha nie mógł sobie pozwolić, tym bardziej że spodziewał się zapewne rychłego zgonu swej protektorki i mocodawczyni, Anny Jagiellonki (nota bene zmarłej w tym samym 1596 r., w którym Sadłocha stał się posiadaczem wsi Drozdy) ${ }^{145}$.

W latach 90. XVI w. w działalności publicznej Kaspra Sadłochy w coraz większym stopniu uwidaczniał się także rys filantropijny. W 1592 r. zakończono prowadzoną z jego inicjatywy odbudowę kaplicy Najświętszego Sakramentu w kolegiacie warszawskiej, był także dobroczyńcą licznych szpitali, w tym zwłaszcza Świętego Ducha (sprawował tam funkcję prepozyta, zapisał też na rzecz szpitala 400 złotych polskich ${ }^{146}$ ). W 1597 r. wystapił jako egzekutor testamentu Zacheusza Piekarskiego, kanonika warszawskiego i pułtuskiego, przekazując na ręce rajców Starej Warszawy dwieście złotych polskich w gotówce z przeznaczeniem na remont kościoła św. Jana Chrzciciela oraz jego wieży, jak też pięćdziesiąt złotych jako jałmużnę dla ubogich ze szpitala Świętego Ducha ${ }^{147}$. Na początku XVII stulecia także „wielebny pan Kacper Sadłocha” wystapił jako donator. Zapewne w 1602 r. „powodowany miłością wobec społeczności starej Warszawy, [...] kazał zwołać we własnej obecności znakomity urząd radziecki i w ich obecności tenże wielebny pan prepozyt, chociaż do pewnego stopnia chory na ciele, zdrów jednak na umyśle, [...] temuż znakomitemu urzędowi radzieckiemu [...] sumę pięciuset złotych polskich w przeliczonej gotówce [...] darował, skutecznie i rzeczywiście dał oraz przekazał do dyspozycji i bezpośredniego zarządu na użytek rzeczonego starego miasta i jego mieszkańców [...]"148 . Przy okazji tego niewątpliwie szlachetnego aktu dowiadujemy się, że ,wielebny pan prepozyt” miał problemy z zapłatą zobowiązań finansowych, obciążających go z tytułu posiadania nieruchomości w mieście, którą zapewne, przynajmniej częściowo, puszczał w najem. W uznaniu bowiem uczynionej darowizny „znakomity urząd radziecki, [...] złożywszy mu podziękowania, w charakterze odwzajemnienia się nie tylko darował i puścił w niepamięć wielebnemu panu prepozytowi wszystkie razem i każdy z osobna czynsze, obciążenia, dochody i przychody cywilne, pochodzące z własnej kamienicy tegoż wielebnego pana prepozyta, znajdującej się i położonej na gruncie miejskim pomiędzy kamienicami przewielebnego pana biskupa poznańskiego, obecnie i w przyszłości, z jednej strony oraz sukcesorów zmarłego Abrahama Hegnera, mieszczanina warszawskiego z drugiej, aż do dnia dzisiejszego niezapłacone, lecz także zwolnił go dożywotnio z płacenia tychże przychodów i czynszów cywilnych [...]"149. Niedługo po tym wydarzeniu, w poniedziałek po niedzieli Cantate 1603 r., Sadłocha, najwyraźniej sam nie czując się już na siłach, „nadał i przekazał przez ręce czcigodnego pana Daniela Fryderyka, kanonika i oficjała warszawskiego kościoła kolegiackiego św. Jana Chrzciciela, dwieście złotych polskich [...] na budowę tegoż warszawskiego kościoła kolegiackiego [...]"150 . Zmarł zapewne wkrótce po wyżej opisanej dyspozycji majątkowej. Pochowany został w warszawskiej kolegiacie, w której pod koniec życia był prepozytem i gdzie wystawiono mu epitafium, które widział jeszcze Julian Bartoszewicz ${ }^{151}$.

Działalność publiczna i realizacje własne stawiają Sadłochę w rzędzie najciekawszych postaci ówczesnego Królestwa Polskiego. Dobrze zachowany, skrupulatnie prowadzony

\footnotetext{
145 BOGUCKA, Anna Jagiellonka..., s. 178.

146 Zofia PODGÓRSKA-KLAWE, Szpitale warszawskie 1388-1945, Warszawa 1975, s. 50.

${ }^{147}$ AGAD, SW, 14, k. $175-175 \mathrm{v}$.

148 AGAD, SW, 15, k. 286v.

${ }^{149}$ AGAD, SW, 15, k. 286v.

${ }^{150}$ AGAD, SW, 15, k. 364.

${ }^{151}$ BARTOSZEWICZ, op. cit., s. 26.
} 
rejestr wydatków warszawskiego kanonika i sekretarza królewskiego pozostaje niezwykle ważnym źródłem, umożliwiającym szczegółowe zapoznanie się z funkcjonowaniem dużej, królewskiej inwestycji z ostatniej ćwierci XVI w. od jej zaplecza organizacyjnego i materiałowego. Słabo poznanym zagadnieniem były np. kwestie związane ze sprowadzeniem odpowiedniego budulca oraz zapewnieniem wykwalifikowanych robotników do jego obróbki. O ile brak na obszarze Mazowsza znaczniejszych wychodni kamienia w pełni usprawiedliwia konieczność sprowadzania go z Melsztyna czy z Krakowa, o tyle zadziwia np. niemożność zorganizowania w Warszawie odpowiedniej jakości gliny do formowania dachówek czy też konieczność sprowadzania dla przeprowadzenia jej wypału specjalistów aż z Krakowa. Istotne są także dane na temat składu narodowościowego ekipy budowlanej oraz sposobu, w jaki Sadłocha tym zespołem zarządzał (tu interesujące wydają się zwłaszcza kwestie opieki zdrowotnej, wypłacanych zapomóg czy nagród).

Casus Sadłochy umożliwia także badania nad mentalnością i upodobaniami niedocenianej i słabo dotychczas rozpoznanej grupy społecznej, czyli szlachty miejskiej. Ambitny kanonik konsekwentnie realizował marzenie o własnej, najlepiej położonej extra muros siedzibie, przy czym przynajmniej jedna z realizacji Sadłochy przyjęła znamienną formę wieży ${ }^{152}$. Jak widać, ów syn rajcy z Osieka miał aspiracje zbliżone do osób z kręgu elity władzy Królestwa. W tym kontekście działalność publiczna Sadłochy stanowi ważny przyczynek do badań nad rolą kulturotwórczą środowiska sekretarzy królewskich. Późne pojawienie się Sadłochy w tym gronie sprawiło, że ani Mirosław Korolko, ani też Marek Ferenc nie uwzględnili jego osoby w swych pracach ${ }^{153}$. Niemniej, zwłaszcza w końcowym okresie życia Zygmunta Augusta, rola Kaspra w kancelarii królewskiej musiała być znaczna. Wprawdzie trudno zaliczyć Sadłochę do ówczesnej ścisłej elity władzy, jednak jego działalność budowlana, opieka nad szkołą kolegiacką czy wspieranie szpitali warszawskich potwierdzają spostrzeżenia o środowisku kancelarii monarszej jako swoistej elicie kulturalnej kraju ${ }^{154}$. Odmienny od większości sekretarzy królewskich był jedynie gust kanonika Sadłochy jeśli chodzi o architekturę ${ }^{155}$. Zamiast „,na sposób włoski” budować wille czy kaplice kopułowe wolał on zrealizować wieżę mieszkalną - tradycyjny, sięgający korzeniami XV stulecia model siedziby rycerskiej ${ }^{156}$.

Postać kanonika Sadłochy wciąż wymaga dalszych badań. Szczególnie istotne wydaje się prześledzenie jego edukacji oraz uchwycenie początku kariery dworskiej. Luki w stanie naszej wiedzy nie wpływająjednakże znacząco na ocenę jego działalności budowlanej oraz inwestycyjnej. Mam więc nadzieję, że przedstawiony tu materiał będzie stanowił

\footnotetext{
${ }^{152}$ Nie był w owym pragnieniu wywyższenia się ponad otoczenie osamotniony. Wiemy bowiem, że jeszcze w $1520 \mathrm{r}$. przy domu kanonika Jana z Popielżyna funkcjonowała wieża przystosowana do celów mieszkalnych. Pierwotnie zapewne był to obiekt związany z fortyfikacjami miasta, bowiem aż do 1478 r. kanonicy mieli utrzymywać na nim straż; zob. Ewa SUCHODOLSKA, „Źródła pisane do dziejów zamku książąt mazowieckich w Warszawie”, Kronika Zamkowa, 2007, nr 1-2 (53-54), s. 203.

153 Por. Mirosław KOROLKO, „Poczet sekretarzy królewskich Zygmunta Augusta (1548-1572)”, Odrodzenie i Reformacja w Polsce, 31:1986, s. 45-84; id., Seminarium Rzeczpospolitej..., s. 191-242; Marek FERENC, „Sekretarze «nadworni» Zygmunta Augusta", Studia Historyczne, 40:1997, nr 1(156), s. 31-44.

154 WYCZAŃSKI, op. cit., s. 96-131; KOROLKO, Seminarium Rzeczpospolitej..., s. 111-136; KAJZER, „Kaplice i wille...", s. 373-383.

${ }^{155} \mathrm{Na}$ temat roli środowiska sekretarzy królewskich w rozpowszechnieniu wzorców architektury rodem z Italii zob. KAJZER, „Kaplice i wille...”, s. 373-374.

${ }^{156}$ Por. Piotr LASEK, Turris fortissima nomen Domini. Murowane wieże mieszkalne w Królestwie Polskim od $1300 \mathrm{r}$. do połowy XVI w. red. Andrzej J. BARANOWSKI, Warszawa 2013, s. 191-216 (Dysertacje doktorskie Instytutu Sztuki Polskiej Akademii Nauk, red. Joanna SOSNOWSKA, I).
} 
istotne źródło wiedzy dla badaczy architektury XVI stulecia na Mazowszu, jak też historyków zajmujących się dziejami stanu szlacheckiego w I Rzeczypospolitej. Wydaje się także, że przypadek Kaspra Sadłochy winien zwrócić baczniejszą uwagę na nadzorców budów królewskich czy magnackich. Nie zawsze bowiem ludzie ci byli jedynie zarządcami, odpowiedzialnymi za rozliczenia między inwestorem a budowniczymi. Niewątpliwie w niektórych przypadkach studia nad funkcją i zakresem obowiązków osób określanych mianem praefectus fabricae moga prowadzić do konstatacji, że mieli oni duży wpływ na przebieg procesu budowy, a w konsekwencji na ostateczny kształt dzieła architektury. Wreszcie żywię nadzieję, że przedstawione tu spostrzeżenia będą stanowiły asumpt do podjęcia badań tzw. Pałacu Prymasowskiego i być może wyodrębnienia z jego murów reliktów drugiej siedziby Kaspra Sadłochy Niżeńskiego. 


\section{Kasper Sadtocha Niżeński Bearing the Korczak Coat of Arms as Investor, Construction Supplier, and Royal Praefectus Fabricae}

The figure of Kasper Sadłocha Niżeński until now has remained on the margin of the interests of researchers into $16^{\text {th }}$-century Warsaw architecture. Meanwhile, his public activity was to a great extent related precisely to architecture, while the scale and extent of the projects he was assigned allow to think that he was really very well-updated on the realities of construction projects of the period. What is more, apart from the supervision and implementation of the King's building undertakings, Sadłocha was also consistently involved in implementing his own projects. Information on his seats provide much knowledge of both intellectual horizons of Sadłocha and his aspirations, and the investment projects of the then nobility.

From Lesser Poland, Kasper was born in Osiek, in the Sandomierz Region. He bore the Korczak coat of arms, and throughout most of his life he would write of himself as 'of Osiek', he was thus a representative of town gentry. He began his career at the court of Queen Bona, to later, following her death, affiliate himself with her son Sigismund Augustus. It was on the latter's order that as of 1568 Sadłocha supervised the construction of the first permanent bridge on the Wisła in Warszawa (in cooperation with Warszawa Starost Zygmunt Wolski), while as of 1569 also the extension of the Warszawa Castle. By the end of the King's life he was referred to as his Secretary.

Sadłocha’s public activity places him among the most intriguing individuals of the then Kingdom of Poland. A well-preserved, meticulously kept register of expenses of the Warszawa Canon and Royal Secretary, continues to serve as a precious source providing details of the operations of a royal major investment from the last quarter of the $16^{\text {th }}$ century as seen from organizational and material background.
For instance, what has not been sufficiently investigated is the issue of supplying adequate building materials and securing qualified workforce for their treatment. Essential information is also that on the national composition of the building team as well as the means Sadłocha used to run this team (particularly interesting in this respect seem the issues of healthcare, paid out, aid or prizes).

Moreover, Sadłocha's case allows to investigate mentality and predilections of the underestimated and as yet not thoroughly identified social group, namely urban nobility. The ambitious Canon was consistent while implementing his dream of having his own, preferably extra muros seat; interestingly, at least one of Sadłocha's projects was in a peculiar form of the tower. The relics of the described building are still clearly visible in the cellars of the eastern wing of the former Charity Society's edifice, today part of the Warsaw Archdiocese Caritas at 62 Krakowskie Przedmieście Street.

As can be seen, the son of the Osiek Councillor boasted aspirations close to those from the elite of the ruling circles in the Kingdom. In this context the public activity of Sadłocha is an important contribution to the research into the culture-forming role played by royal secretaries. Although it is not possible to rank Sadłocha among the then ruling elite, his construction activity, care of the Collegiate school, or support provided to Warsaw hospitals confirm the observation that the circle of Royal Chancellery people constituted a cultural elite in their country. However, what distinguished Canon Sadłocha was his taste in architecture. Instead of following the 'Italian manner' when constructing villas or domed chapels, he preferred to raise a residential tower: a traditional model of a knight's residence well rooted in the $15^{\text {th }}$ century. 
